\title{
Market orientations, product innovation and organizational performance: A case study on selected beer factories found in Ethiopia
}

Nigist Kelemu Fentaw ( $\sim$ nigistkelemu92@gmail.com )

\section{Research}

Keywords: Market Direction, Dispatch technique, item execution, hierarchical execution, benefit and money related execution

Posted Date: August 14th, 2020

DOI: https://doi.org/10.21203/rs.3.rs-18774/v2

License: (c) (1) This work is licensed under a Creative Commons Attribution 4.0 International License. Read Full License 


\section{Abstract}

Overview was led to explore the relationship between advertise direction, creation process, item execution, authoritative execution and budgetary execution. The motivation behind this overview was to research connections among showcase direction, dispatch technique, item execution, hierarchical execution, gainfulness and budgetary execution. Target populaces were representatives of chose Ethiopian lager processing plants BGI Ethiopia who are as of now devouring the item; from which test was resolved through critical inspecting strategy. Asked information was gathered by means of study poll, direct relapse examination was led to check the relationship among driving variable. At last it was discovered that organizations' gainfulness and money related execution are being impacted by advertise direction, dispatch technique, item execution and hierarchical execution. Firms are prescribed to concentrate on improving business sector direction, dispatch system, item execution and hierarchical execution to support productivity and budgetary execution.

\section{Introduction}

Market direction is a business culture that (1) puts the most elevated need on the productive creation and support of unrivaled incentive for clients while thinking about the enthusiasm of different partners; (2) gives standards to practices with respect to the hierarchical age, dispersal and responsiveness to advertise data (Deshpande' et al. 1993; Kohli and Jaworski 1990; Narver and Slater 1990, 1998). Also, Chase and Morgan (1995) express that a market-arranged culture delivers a supportable upper hand and, accordingly, prevalent since a long time ago run authoritative execution. In accordance with this thinking analysts widely have sought after a comprehension of the connection between showcase direction and execution (Homburg and Pflesser 2000).

Item advancement has been characterized as the emphasis on the requirements of the present clients and the more extensive client markets (Ansoff, 1987). Kotler (2000) says in item improvement a firm stays in its present markets yet grows new items for these business sectors. The view that new items are useful to the monetary soundness of supporting firms is all around contended by researchers. Schumpeter (1934), for example, opined that creative new items when originally presented face restricted direct challenge and, subsequently, permit moderately high benefits to supporting firms. After some time these high benefits are probably going to vanish on account of impersonation and rivalry, he contended, however firms that continue presenting inventive new items might have the option to have high gainfulness for a supported period. Enormous and developing writing bolsters the positive connection among's advancement and firm benefit. The quantity of advancements created by firms positively affected their working net revenue, Geroski et al. (1993). As per Clark and Fujimoto (1991) execution in an advancement venture is dictated by a company's item technique and by its capacities in general procedure and association. They further case that organizations items help to shape the market condition; the nature of the market condition changes as buyers and contenders gain from new items and administrations. Inventive execution is a significant driver for firm development specifically the mix of item and procedure advancements that altogether improves firm development, Goedhuys and Veugelers 
(2008). Money related markets might be adjusted pointedly to item advancement results in traded on an open market firms (Anurag and Nelson, 2004).

Drift there are various investigations led on various nations on this issues in alternate points of view, in Ethiopian setting similarly as the specialists information there is no examination works legitimately or by implication directed on this issues. Along these lines, the aim of this investigation tries to address the interceding impact of new item advancement in connection with showcase direction on authoritative money related execution: the instance of Ethiopian Brew Production lines.

\section{Research Framework}

\subsection{Financial Performance}

Execution might be characterized as the impression of the manner by which the assets of an organization are utilized in the structure which empowers it to accomplish its goals. As indicated by Heremans (2007), budgetary execution is the work of monetary markers to quantify the degree of target accomplishment, commitment to making accessible money related assets and backing of the speculation openings. Rutagi (1997) characterizes budgetary execution with respect to how well an association is performing. Different analysts characterize execution of the association as the degree to which an association accomplishes its expected result Namisi (2002).The general suspicion among the two specialists and experts is that powerful sheets lead to successful association. From either an interior long haul gainfulness or outside investor point of view, there means that great sheets might have the option to increase the value of the association (Epstein et al., 2003).

\subsection{Company performance}

Zahra and Hayton (2008) built up that the writing on execution is extremely broad, yet that it shows an absence of agreement with regards to the importance of the term. Brush and Vanderwerf (1992) point out, that the utilization of the expression "execution" by specialists incorporates numerous builds estimating elective parts of execution. This is steady with the finding of Murphy et al. (1996) who, after a thorough writing survey, had the option to disconnect an aggregate of 71 unique proportions of execution. Disregarding this clear bounty, by far most of studies have utilized monetary proportions of execution (Hansen, 2010).

The raison d'être for this obsession with monetary execution measures, is found halfway in the way that budgetary exhibition is at the center of the authoritative control frameworks and somewhat in that it is one of the most effectively quantifiable estimating instruments. Be that as it may, this has made observational research depend on a restricted arrangement of bookkeeping proportions of money related execution, for example, rate of (return on initial capital investment), return on resources (ROA), or profit per share (Pandian, et al., 2006; Sapienca et al., 1988). 
The advancement the board association (IMO) is liable for growing new items and innovations (PérezLuñoa et al., 2011). Science and innovation from the outside condition are joined with the organization's in-house abilities, information and skills to grow new items and advances. The obligations that fall inside the space of advancement the executives incorporate innovative work (Research and development). Thus, Research and development comprises of those exercises and obligations running from understanding dynamic innovation to creating thoughts to growing new items and advances.

\subsection{Conceptual Framework and Hypothesis development}

Researchers will use the following conceptual framework as a study guideline.

Conceptual Framework and Hypotheses

Connections over the structure obstructs right now: direction, new item advantage, the capability in dispatch exercises (advertise testing, dispatch planning, dispatch procedure, and dispatch strategies), new item execution, and hierarchical execution. It is proposed here that a market-arranged culture is connected emphatically to item preferred position and dispatch capability. It additionally is placed that the capacity of market-situated firms to create and to dispatch items that fit client needs prompts predominant new item execution. Prevalent new item execution in this way influences authoritative exhibition. A market-situated culture, be that as it may, likewise can impact the capability in other advertising exercises (i.e., evaluating, dissemination, and advancement) and other NPD exercises (i.e., predevelopment and improvement) other than the dispatch exercises. Thusly, advertise direction additionally is guessed to affect new item execution and hierarchical execution. Next, the theories will be created.

\subsubsection{The Relationship between Market Orientation and Product Advantage}

Item advantage alludes to the advantages that clients get from the new item (Calantone and di Benedetto 1988). The impact of a market-arranged culture on item advantage is a subject of discussion (Lukas and Ferrell 2000). A few creators have proposed that a solid market-arranged culture may prompt impersonations and to hardly new items (Bennett and Cooper 1981). Others add that listening also near clients can establish a boundary to commercializing new innovation and can prompt less intensity (Christensen and Grove 1996). Conversely, there is solid theoretical and observational proof that a market situated culture improves the making of better an incentive for clients' relative than contenders (Slater and Narver 1998, 1999). What's more, the observational proof that showcase direction has a positive association with new item achievement (Bread cook and Sinkula 1999a; Pelham and Wilson 1996; Slater and Narver 1994a) recognizes that advertise or iented firms create items with more noteworthy bit of leeway over the challenge since item advantage is the main factor influencing new item execution (Henard and Szymanski 2001). At long last, the recommendation that a market-arranged culture prompts more prominent consumer loyalty and rehash business additionally verifiably recognizes that advertise situated firms create items with more noteworthy preferred position over challenge (Atuahene-Gima 1996). Hence, it is conjectured that 


\subsubsection{The Relationship between Market Orientation and the Proficiency in Launch Activities}

Item advantage alludes to the advantages that clients get from the new item (Calantone and di Benedetto 1988). The impact of a market-oA dispatch plan for another item comprises of those exercises important to show another item to its objective market and to start to create pay from offers of the new item (Kotler 2003). These exercises have been alluded to under the aggregate terms of dispatch procedure, advertise passage, item dispatch, presentation, or market dispatch (Hultink et al. 1998). Researchers who express that a market-situated culture encapsulates qualities and convictions that control authoritative exercises improving execution verifiably recognize the impact of market direction on the dispatch exercises. For instance, as indicated by Deshpande' and Farley (1998), showcase direction speaks to the arrangement of cross-useful procedures and exercises coordinated at making and fulfilling clients through constant needs-evaluation. So also, Dough puncher and Sinkula (1999a) declare that a market-arranged culture gives a binding together concentration to the endeavors and undertakings of people and divisions in associations, in this manner prompting predominant execution.

Atuahene Gima (1995) offers some exact help for the recommendation that a market-situated culture guides authoritative exercises by demonstrating that a market-arranged culture emphatically impacts the capability in the preparation of offers and cutting edge work force, post-dispatch assessment, and market test ing. The showcasing and NPD literary works, be that as it may, give an increasingly exhaustive rundown of dispatch exercises (Hultink et al. 1998). We center here around the capability in showcase testing, dispatch planning, dispatch technique, and dispatch strategies that together spread the full broadness of the space of dispatch exercises (Kotler 2003).

Market testing identifies with the exercises required to test both the physical item and the dispatch strategies in the objective market. Dispatch planning relates to a planning task required to create, to actualize, and to screen dispatch system and strategies dispatch methodology identifies with the assignments required for noting the what, where, when, and for what reason to dispatch questions (e.g., dividing, focusing on, and situating). Dispatch strategies include the undertakings identified with the advertising blend choices (i.e., item strategies, circulation, estimating, and advancement) on the most proficient method to dispatch the new item. In view of calculated proof and on Atuahene Gima's (1995) observational discoveries, it is placed here that advertise direction emphatically impacts the capability in the dispatch exercises:

\section{H2: Market orientation of the firm is positively related with company's proficiency on (1) market testing, (2) launch budgeting, (3) launch strategy, and (4) launch tactics.}

\subsubsection{The Relationship between New Product Advantage and New Product Performance}

Rogers (1983) suggested that item advantage, similarity, preliminary capacity, and watch capacity are connected decidedly to selection, while unpredictability and saw chance are connected contrarily to 
appropriation (Gatignon and Robertson 1985). Be that as it may, item advantage reliably shows up as the most significant item trademark in clarifying the appropriation and achievement of the new item (Henard and Szymanski 2001; Montoya-Weiss and Calantone 1994). There-fore, it is conjectured that

\section{H3: Product advantage is positively related with new product performance.}

\subsubsection{The Relationship between Launch Proficiency and New Product Performance}

Past research has demonstrated that the capability in NPD exercises is a basic necessity for new item execution. For instance, Maidique and Zirger (1984) reason that new item achievement is almost certain when "the creating association is capable in advertising and submits a lot of its assets to selling and advancing the item". Tune and Repel (1996) connect proportions of new item accomplishment to proficiencies in statistical surveying and dispatch. Cooper (1979) reports connections between new item achievement and proportions of advancement capability, which incorporates proportions of test promoting and dispatch capability.

A subsequent report by Cooper and Kleinschmidt (1987) reports comparative outcomes, as do later investigations of Australian (Dwyer and Mellor 1991), Chinese (Melody and Repel 1994), and Japanese (Tune and Repel 1997) firms. More proof for the positive effect of dispatch capability on new item execution has been given by, for instance, Biggadike (1979), Green et al. (1995), and Hultink et al. (1998). Together these discoveries propose that the capability in dispatch exercises is a crucial prerequisite for new item achievement. In this manner, we conjecture that:

H4: Company's proficiency on (1) market testing, (2) launch budgeting, (3) launch strategy, and (4) launch tactics, is positively related with new product performance.

\subsubsection{The Relationship between Market Orientation and New Product Performance}

Pastry specialist and Sinkula (1999a), Pelham and Wilson (1996), and Slater and Narver (1994a) have indicated that a market direction decidedly influences new item execution. The method of reasoning for advertise direction being emphatically identified with new item execution is established in the conviction that a market-situated culture exemplifies authoritative qualities and convictions that manage exercises, including NPD exercises that lead to prevalent hierarchical execution. For instance, Slater and Narver (1994a) note that showcase direction makes the fundamental practices for making an incentive for purchasers and along these lines for making ceaseless unrivaled execution. In like manner, Ruekert (1992) attests that a market direction gives a binding together concentration to the endeavors and ventures of people and offices in associations, subsequently prompting predominant execution. In this manner, it is speculated that

H5: Firm's market orientation is positively related with new product performance.

\subsubsection{The Relationship between Market Orientation and Organizational Performance}


Authoritative execution alludes to the association's market and monetary execution, which is emphatically identified with the associations financial worth (Slater and Narver 1994a). We see authoritative execution in serious terms (i.e., contrasted with applicable contenders), in light of the fact that a market-situated culture has been placed as one of an association's serious capacities and wellsprings of favorable position (Chase and Morgan 1995).

The writing contends that a market-arranged culture gives a bringing together focal point of authoritative endeavors in the conveyance of significant worth to clients while likewise giving a near stimulus contenders' exercises (Kohli and Jaworski 1990). Along these lines, a market-situated firm is bound to accomplish elevated levels of consumer loyalty; to continue existing clients faithful; to draw in new clients; and therefore to achieve the ideal degree of development, piece of the overall industry, and thus of authoritative execution (Homburg and Pflesser 2000). Along these lines, it is estimated that

\section{H6: Firm market orientation is positively related with organizational performance.}

\subsubsection{The Relationship between New Product Performance and Organizational Performance}

A significant piece of the NPD writing has demonstrated that new item execution is connected emphatically to hierarchical execution (Griffin and Page 1996; Hultink et al. 1998; Montoya-Weiss and Calantone 1994). The basis for new item execution getting progressively significant for hierarchical execution is that organizations stand up to expanded degrees of rivalry, quickly changing business sector conditions, higher paces of specialized outdated nature, and shorter item life cycles (Griffin 1997). In these conditions, new items serve to oblige the vulnerabilities a firm faces in its enterprising condition.

Observational research additionally uncovers the significance of new item execution for hierarchical execution. For instance, Griffin (1997) reports that best-practice firms acknowledge 49 percent of their deals from items created and propelled over the most recent five years and that new item execution represents one-fourth of the inconstancy in hierarchical execution. So also, Terwiesh et al. (1998) report that new item execution clarifies, contingent available setting, somewhere in the range of 30 and 70 percent of hierarchical productivity fluctuation. As needs be, it is speculated that

\section{H7: New product performance is positively related with organizational performance.}

\section{Methodology}

\subsection{Research Design}

The examination configuration utilized under this investigation was cross-sectional overview kind of worldview. A cross-sectional study offers the chance to gather information across various brew processing plants and test this relationship. Regarding the timeframe over which information was gathered, over the different brew organizations, a cross-sectional overview was discovered proper. Further, it was perfect in light of the fact that the specialists planned to gather engaging information that was 
concurred measurable treatment to take into consideration theory testing to concoct target ends (Cooper and Schindler, 2003).

\subsection{Target Population}

This study considered all employees of selected Ethiopian beer factories (BGI Ethiop, Meta ABO and Harar Brewery) who are currently consuming the product. Therefore the target respondents of the study was all employees of Ethiopian beer enterprises.

\subsection{Sampling Design}

The researchers used purposive/judgmental sampling method to determine the sample size of the research. Researchers prefer this sample design purposely to include selected employees of each beer factories who are currently drinking beer products. This study took employees of each factory as respondents because researchers assumed that these individuals have better knowledge regarding the products and organization.

\subsection{Sample size determination}

This research project considered purposefully selected 3 beer factories, BGI Ethiop (Amber, Castel and St. George), Meta ABO (Meta beer and Meta premium) and Harar Brewery (Harar beer and Hakim stout) in Ethiopia. Researchers took all employees of each beer factories who currently drinks beer. These beer factories are selected because they have different products as compared with other beer factories.

\subsection{Data sources}

Researchers used both primary and secondary data. Primary data was collected from the employees of Ethiopian beer factories using survey Questionnaire. Secondary Data was be gathered from company audited financial statements operating the last 5 years.

\subsection{Data Collection Instruments}

Survey questionnaire and audited financial statements were used to gather the relevant quantitative data. Researchers also conducted interview for general managers in each firm to collect qualitative data which was used to triangulate the research framework. The constructs were measured using five-point multiitem scales drawn from previous studies.

\subsection{Reliability and Validity Test}


The internal consistency and convergent validity of the scales was investigated by performing a series of confirmatory factor analyses at the first-order and second-order level. The discriminated validity was assessed across the subscales by estimating two-factor first-order models for each possible pair of subscales twice: once constraining the correlation between the latent variables to unity and once freeing the parameter. A chi-square difference test assessed whether the chi-square of the unconstrained model which was significantly lower that provided evidence of discriminated validity.

Researchers conducted pilot testing before collecting the overall input of the study to check the internal consistency (precision) of each constructs using Cronbach alpha via SPSS software questionnaires.

\subsection{Data Analysis}

In this study, researchers are referring mixed approach hence both quantitative and qualitative data analysis techniques was employed. Linear regression analysis was conducted to measure the relationship between the dependant and independent variables. Researchers used qualitative data to triangulate the structure of the study. The study also investigated the cause and effect relationship between mediating variables.

\section{Result And Discussion}

\subsection{Data Sample Information}

A total of 240 questionnaires were distributed at selected Ethiopian beer factories (BGI Ethiop, Meta ABO and Harar Brewery) Out of which 227 questionnaires were returned, which researchers used as an input for analysis to present the findings and draw conclusion. Further the data analysis was performed to reach the findings, hence the analysis, results and discussions are presented as follows.

Table 4.1 Distribution of back ground variable $(\mathrm{N}=227)$

\begin{tabular}{|c|l|l|l|l|}
\hline Gender & Frequency & Percent & Valid Percent & Cumulative Percent \\
\hline Valid Female & 91 & 40.1 & 40.1 & 40.1 \\
Male & 136 & 59.9 & 59.9 & 100.0 \\
Total & 227 & 100.0 & 100.0 & \\
& & & & \\
\hline
\end{tabular}

Source: survey on March 2010

Table 4.1 reveals distribution of respondents background information of the first variable; gender of the respondent which indicate that $91(40.1 \%)$ of the respondent are female while $136(59.9 \%)$ of them are male. Hence most of the respondent in this project are male. 
Table 4.2 Distribution of educational back ground variable $(\mathrm{N}=227)$

\begin{tabular}{|l|l|l|l|l|}
\hline Educational level of respondents & Frequency & Percent & Valid Percent & Cumulative Percent \\
\hline Valid Reading and writing & 3 & 1.3 & 1.3 & 1.3 \\
Complete grade ten/ twelve & 7 & 3.1 & 3.1 & 4.4 \\
Diploma holder & 54 & 23.8 & 23.8 & 28.2 \\
Degree holder & 77 & 33.9 & 33.9 & 62.1 \\
Masters and above & 86 & 37.9 & 37.9 & 100.0 \\
Total & 227 & 100.0 & 100.0 & \\
\hline
\end{tabular}

\section{Source: Survey on March 2010}

Table 4.2 shows analysis result of educational background of the study respondents which indicates that $3(1.3 \%)$ of the respondents are able only reading and writing, $7(3.1 \%)$ of them are complete grade ten, $54(23.8 \%)$ of them are diploma holders, $77(33.9 \%)$ of them are degree holder and $86(37.9 \%)$ of the respondents are master holder and above. This indicates that most of the study respondents are degree and master holders.

\subsection{Measuring the association between basic study variable and researches constructs}

This study was conducted to investigate the relationship between market orientation, new product performance, and organization performance and organization profitability. Therefore in this part of the study, a keen attention is given to measure the relationship among the leading constructs (market orientation, new product performance, and organization performance and organization profitability). So here the analysis result and discussion of basic variables are displayed below.

Table 4.3 Organization's sales efficiency and its relation with market direction related variables $(\mathrm{N}=\mathbf{2 2 7})$

\begin{tabular}{|l|c|l|}
\hline Independent variables & Method & $\begin{array}{l}\text { Correlation with organizational } \\
\text { sales efficiency }\end{array}$ \\
\hline Organization performance related & Pearson & 1 \\
& Correlation & \\
& Sig. (2-tailed) & \\
Markestion one & N & 227 \\
& Pearson & -.028 \\
& Correlation & \\
Market related question one & Sig. (2-tailed) & .669 \\
& N & 227 \\
& Pearson Correlation & .100 \\
& Sig. (2-tailed) & .134 \\
Market related question two & $\mathrm{N}$ & 227 \\
& Pearson Correlation & -.067 \\
& Sig. (2-tailed) & .315 \\
& $\mathrm{~N}$ & 227 \\
\hline
\end{tabular}

\section{Source: Survey on March 2010}

Table 4.3 shows regression analysis result of organization's sales efficiency and company's production capacity relative to its competitor's production capacity, product quality in-terms of 
production input and quality of company's overall information handling and dissemination process. As it is displayed in the table 4.3 the coefficients of the correlation results are -.028, .134 and -.067 which indicates that organization's sales efficiency is positively related with its product quality while it is negatively related with competitor's production capacity and overall information handling and dissemination process.

Table 4.4 Organization's market share advantage and it's relation with market directed variables $(\mathrm{N}=227)$

\begin{tabular}{|c|c|c|}
\hline Independent variables & Method & $\begin{array}{l}\text { Correlation with organizational market share } \\
\text { advantage over competitors }\end{array}$ \\
\hline $\begin{array}{l}\text { Organization performance } \\
\text { related question two }\end{array}$ & $\begin{array}{l}\text { Pearson } \\
\text { Correlation } \\
\text { Sig. } \\
\text { tailed) } \\
\mathrm{N}\end{array}$ & 227 \\
\hline Market related question one & $\begin{array}{l}\text { Pearson } \\
\text { Correlation } \\
\text { Sig. (2- } \\
\text { tailed) } \\
\mathrm{N}\end{array}$ & $\begin{array}{l}.024 \\
.716 \\
227\end{array}$ \\
\hline 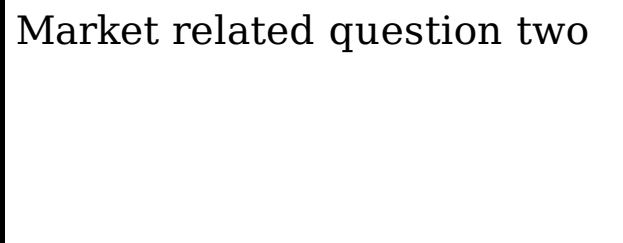 & $\begin{array}{l}\text { Pearson } \\
\text { Correlation } \\
\text { Sig. (2- } \\
\text { tailed) } \\
\mathrm{N}\end{array}$ & $\begin{array}{l}.025 \\
.713 \\
227\end{array}$ \\
\hline Market related question three & $\begin{array}{l}\text { Pearson } \\
\text { Correlation } \\
\text { Sig. (2- } \\
\text { tailed) } \\
\mathrm{N}\end{array}$ & $\begin{array}{l}.111 \\
.097 \\
227\end{array}$ \\
\hline
\end{tabular}

Source: Survey on March 2010

Table 4.4 displays regression analysis result of organization's market share advantage and company's production capacity relative to its competitor's production capacity, product quality in-terms of production input and quality of company's overall information handling and dissemination process. As it is indicated by table 4.4 the coefficients of the correlation results are $.024, .025$ and .111 which implies that organization's market share advantage is positively related with its production capacity relative to its competitors production capacity, product quality in-terms of production input and quality overall information handling and dissemination process.

Table 4.5 Organization's relative profitability and its relationship with market directed variables $(\mathrm{N}=\mathbf{2 2 7})$ 


\begin{tabular}{|l|l|l|}
\hline Independent variables & Method & $\begin{array}{l}\text { Correlation with organization's } \\
\text { relative profitability }\end{array}$ \\
\hline Organization performance related & Pearson & 1 \\
& Correlation & \\
& Sig. (2-tailed) & \\
question three & N & 227 \\
& Pearson & -.021 \\
& Correlation & \\
Market related question two & Sig. (2-tailed) & .758 \\
& N & 227 \\
& Pearson & -.043 \\
& Correlation & \\
& Sig. (2-tailed) & .515 \\
Market related question three & N & 227 \\
& Pearson & .018 \\
& Correlation & \\
& Sig. (2-tailed) & .785 \\
& N & 227 \\
\hline
\end{tabular}

Source: Survey on March 2010

Table 4.5 shows regression analysis result of organization's relative profitability and company's production capacity relative to its competitor's production capacity, product quality in-terms of production input and quality of company's overall information handling and dissemination process. As it is indicated by table 4.5 the coefficients of the correlation results are $-.021,-.043$ and .018 which imply that organization's relative profitability is negatively related with production capacity relative to its competitors production capacity, product quality in-terms of production while it is positively related with its quality of overall information handling and dissemination process.

Table 4.6 Organization's overall status and its relationship with market related variables $(\mathrm{N}=227)$

\begin{tabular}{|l|l|l|}
\hline Independent variables & Method & $\begin{array}{l}\text { Correlation organization's overall } \\
\text { status }\end{array}$ \\
\hline Organization performance related & Pearson & 1 \\
question four & Correlation & \\
& Sig. (2-tailed) & \\
Market related question one & N & 227 \\
& Pearson & -.050 \\
& Correlation & \\
& Sig. (2-tailed) & .449 \\
Market related question two & N & 227 \\
& Pearson & -.009 \\
& Correlation & \\
& Sig. (2-tailed) & .894 \\
Market related question three & N & 227 \\
& Pearson & .013 \\
& Correlation & \\
& Sig. (2-tailed) & .846 \\
& N & 227 \\
\hline
\end{tabular}


Table 4.6 reveals regression analysis result of organization's overall status and company's production capacity relative to its competitor's production capacity, product quality in-terms of production input and quality of company's overall information handling and dissemination process. As it is shown by table 4.6 the coefficients of the correlation results are $-.050,-.009$ and .013 which implies that organization's overall status is negatively related with its production capacity relative to its competitors production capacity, product quality in-terms of production input while it is positively related with its quality of overall information handling and dissemination process.

Table 4.7 Organization's sales efficiency and its relation with customer related variables $(\mathrm{N}=227)$

\begin{tabular}{|c|c|c|}
\hline Independent variables & Method & $\begin{array}{l}\text { Correlation with organization's sales } \\
\text { efficiency }\end{array}$ \\
\hline $\begin{array}{lll}\text { Organization } & \text { performance } & \text { related } \\
\text { question one } & & \\
& & \end{array}$ & $\begin{array}{l}\text { Pearson } \\
\text { Correlation } \\
\text { Sig. (2-tailed) } \\
\mathrm{N}\end{array}$ & 227 \\
\hline Customer related question one & $\begin{array}{l}\text { Pearson } \\
\text { Correlation } \\
\text { Sig. (2-tailed) } \\
\text { N }\end{array}$ & $\begin{array}{l}.037 \\
\\
.576 \\
227\end{array}$ \\
\hline Customer related question two & $\begin{array}{l}\text { Pearson } \\
\text { Correlation } \\
\text { Sig. (2-tailed) } \\
\text { N }\end{array}$ & $\begin{array}{l}.110 \\
.098 \\
227\end{array}$ \\
\hline Customer related question three & $\begin{array}{l}\text { Pearson } \\
\text { Correlation } \\
\text { Sig. (2-tailed) } \\
\mathrm{N}\end{array}$ & $\begin{array}{l}.178^{* *} \\
.007 \\
227\end{array}$ \\
\hline Customer related question four & $\begin{array}{l}\text { Pearson } \\
\text { Correlation } \\
\text { Sig. (2-tailed) } \\
\mathrm{N}\end{array}$ & $\begin{array}{l}.132^{*} \\
.047 \\
227\end{array}$ \\
\hline
\end{tabular}

Source: Survey on March 2010

Table 4.7 reveals regression analysis result of organization's sales efficiency and its information handling ability about consumer's buying process, information regarding consumer's complaints its involvement on customer relationship management and its ability to threat customers friendly. As it is shown by table 4.7 the coefficients of the correlation results are $.037, .110, .178^{*}$ and $.132^{*}$ which implies that organization's sales efficiency is positively related with its information handling ability about consumer's buying process, information regarding consumer's complaints its involvement on customer relationship management and its ability to threat customers friendly

Table 4.8 Organization's market share advantage and its relation with customer related variable $(\mathrm{N}=227)$ 


\begin{tabular}{|l|l|ll|}
\hline Independent variables & Method & $\begin{array}{l}\text { Correlation organization's relative } \\
\text { market share advange }\end{array}$ \\
\hline Organization performance related & Pearson & 1 \\
& Correlation & & \\
& Sig. (2-tailed) & \\
question two & $\mathrm{N}$ & 227 \\
Customer related question one & Pearson & .098 \\
& Correlation & & \\
& Sig. (2-tailed) & .143 \\
& $\mathrm{~N}$ & 227 \\
Customer related question two & Pearson & $.239^{* *}$ \\
& Correlation & & \\
& Sig. (2-tailed) & .000 \\
& $\mathrm{~N}$ & 227 \\
Customer related question three & Pearson & $.144^{*}$ \\
& Correlation & & \\
& Sig. (2-tailed) & .030 \\
& N & 227 \\
Customer related question four & Pearson & $.181^{* *}$ \\
& Correlation & \\
& Sig. (2-tailed) & .006 \\
& N & 227 \\
\hline
\end{tabular}

Source: Survey on March 2010

Table 4.8 shows regression analysis result of organization's relative market share advantage and its information handling ability about consumer's buying process, information regarding consumer's complaints its involvement on customer relationship management and its ability to threat customers friendly. As it is shown by table 4.8 the coefficients of the correlation results are $.098, .239^{* *}, .144^{*}$ and $.181^{* *}$ which implies that organization's relative market share advantage is positively related with its information handling ability about consumer's buying process, information regarding consumer's complaints its involvement on customer relationship management and its ability to threat customers friendly.

Table 4.9 Organization profit efficiency and its relation with customer related variables $(\mathrm{N}=227)$ 


\begin{tabular}{l|l|l|}
\hline Independent variables & Method & $\begin{array}{l}\text { Organization's } \\
\text { efficiency }\end{array}$ \\
\hline Organization performance related question & Pearson & 1 \\
three & Correlation & \\
& Sig. (2-tailed) & \\
& $\mathrm{N}$ & 227 \\
Customer related question one & Pearson & .122 \\
& Correlation & \\
& Sig. (2-tailed) & .066 \\
& N & 227 \\
Customer related question two & Pearson & .039 \\
& Correlation & \\
& Sig. (2-tailed) & .555 \\
Customer related question three & N & 227 \\
& Pearson & .003 \\
& Correlation & \\
& Sig. (2-tailed) & .961 \\
Customer related question four & N & 227 \\
& Pearson & .092 \\
& Correlation & \\
& Sig. (2-tailed) & .169 \\
\hline
\end{tabular}

Source: Survey on March 2010

Table 4.9 reveals regression analysis result of organization's profit efficiency and its information handling ability about consumer's buying process, information regarding consumer's complaints its involvement on customer relationship management and its ability to threat customers friendly. As it is shown by table 4.9 the coefficients of the correlation results are $.122, .039, .003$ and .092 which indicates that organization's profit efficiency is positive related with its information handling ability about consumer's buying process, information regarding consumer's complaints its involvement on customer relationship management and its ability to threat customers friendly.

Table 4.10 Organization's overall status and its relation with customer related variables $(\mathrm{N}=227)$ 


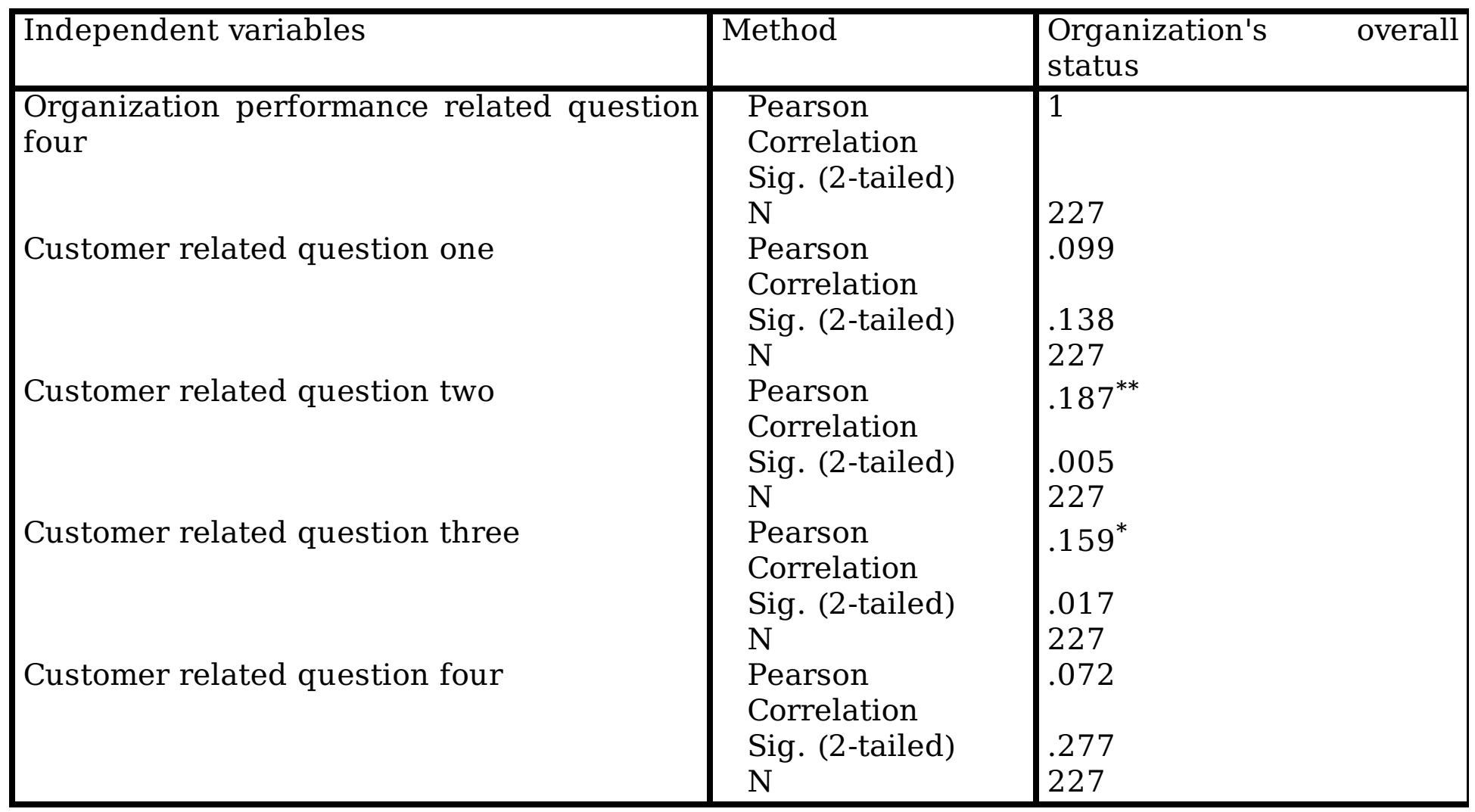

\section{Source: Survey on March 2010}

Table 4.10 shows regression analysis result of organization's overall status and its information handling ability about consumer's buying process, information regarding consumer's complaints its involvement on customer relationship management and its ability to threat customers' friendly. As it is shown by table 4.10 the coefficients of the correlation results are $.099, .187^{* *}, .159^{*}$ and .072 which portrays that organization's overall status is positively related with its information handling ability about consumer's buying process, information regarding consumer's complaints its involvement on customer relationship management and its ability to threat customers friendly.

Table 4.11 Organization's sales efficiency and its relation with competition related variables $(\mathrm{N}=227)$ 


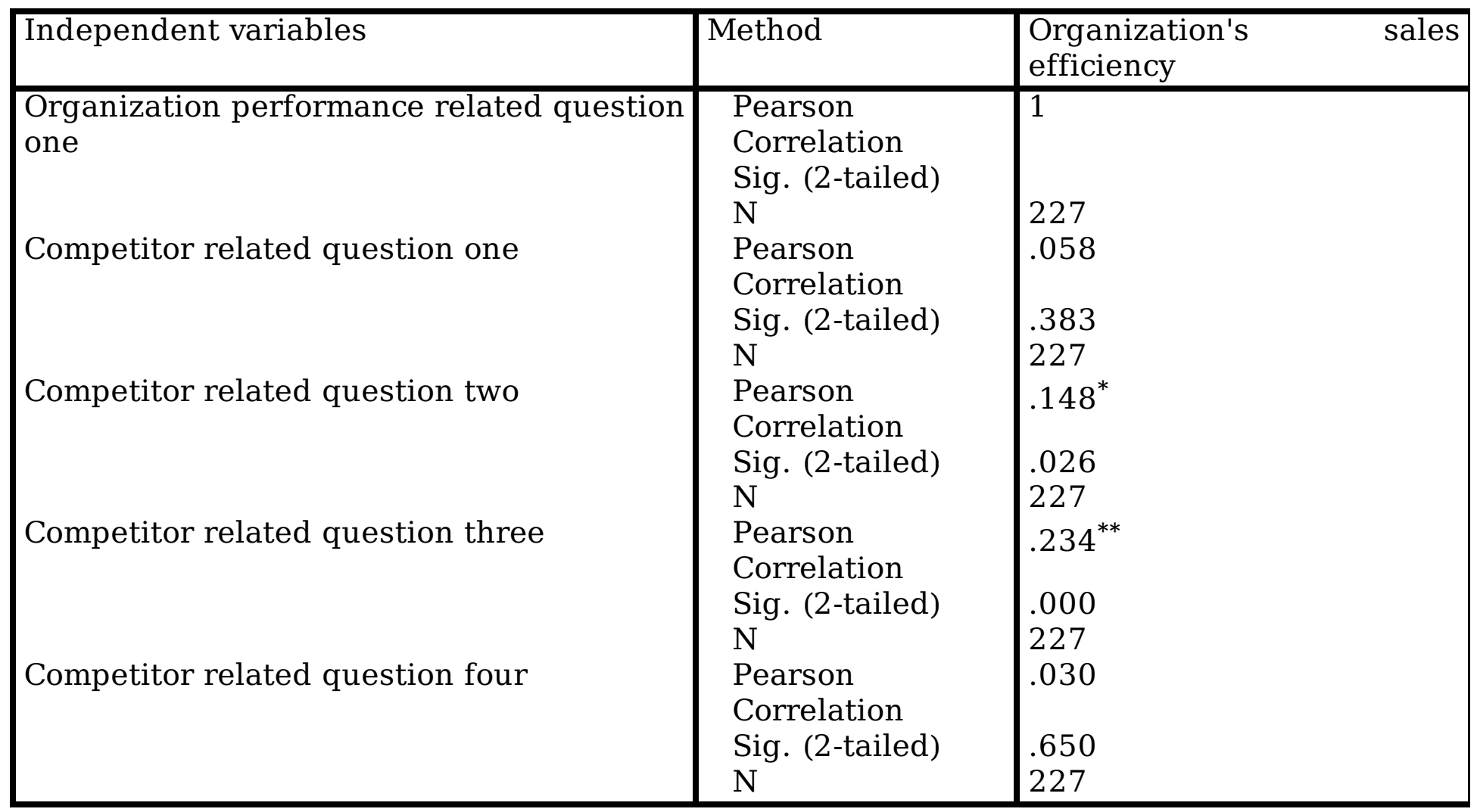

\section{Source: Survey on March 2010}

Table 4.11 shows regression analysis result of organization's sales efficiency and company's information about competitor's customer approaching and handling technique, customer's reason to shift in to competitor's offer, competitors customer relationship management and competitor's product offering and customer attraction method. As it is shown by table 4.11 the coefficients of the correlation results are $.058, .148^{*}, .234^{* *}$ and .030 which indicates that organization's sales efficiency is being positively influenced by company's information about competitor's customer approaching and handling technique, customer's reason to shift in to competitor's offer, competitors customer relationship management and competitor's product offering and customer attraction method.

Table 4.12 Organization's market share advantage and its relationship with competition related variables $(\mathrm{N}=227)$ 


\begin{tabular}{|c|c|c|}
\hline Independent variables & Method & $\begin{array}{lll}\begin{array}{l}\text { Organization's } \\
\text { advantage }\end{array} & \text { market share } \\
\end{array}$ \\
\hline $\begin{array}{lll}\text { Organization } & \text { performance } & \text { related } \\
\text { question two } & & \\
\end{array}$ & $\begin{array}{l}\text { Pearson } \\
\text { Correlation } \\
\text { Sig. (2-tailed) } \\
\mathrm{N}\end{array}$ & $\begin{array}{l}1 \\
227\end{array}$ \\
\hline Competitor related question one & $\begin{array}{l}\text { Pearson } \\
\text { Correlation } \\
\text { Sig. (2-tailed) } \\
\text { N }\end{array}$ & $\begin{array}{l}.020 \\
.767 \\
227\end{array}$ \\
\hline Competitor related question two & $\begin{array}{l}\text { Pearson } \\
\text { Correlation } \\
\text { Sig. (2-tailed) } \\
\text { N }\end{array}$ & $\begin{array}{l}.162^{*} \\
.014 \\
227\end{array}$ \\
\hline Competitor related question three & $\begin{array}{l}\text { Pearson } \\
\text { Correlation } \\
\text { Sig. (2-tailed) } \\
\text { N }\end{array}$ & $\begin{array}{l}.201^{* *} \\
.002 \\
227\end{array}$ \\
\hline Competitor related question four & $\begin{array}{l}\text { Pearson } \\
\text { Correlation } \\
\text { Sig. (2-tailed) } \\
\mathrm{N}\end{array}$ & $\begin{array}{l}.096 \\
.151 \\
227\end{array}$ \\
\hline
\end{tabular}

\section{Source: Survey on March 2010}

Table 4.12 shows regression analysis result of organization's market share advantage and its information about competitor's customer approaching and handling technique, customer's reason to shift in to competitor's offer, competitors' customer relationship management and competitor's product offering and customer attraction method. As it is shown by table 4.12 the coefficients of the correlation results are $.020, .162^{*}, .201^{* *}$ and .096 which indicates that organization's market share advantage is positively related with its information about competitor's customer approaching and handling technique, customer's reason to shift in to competitor's offer, competitors customer relationship management and competitor's product offering and customer attraction method.

Table 4.13 Organization's profit efficiency and its relationship with competition related variables $(\mathrm{N}=227)$ 


\begin{tabular}{|l|l|l|}
\hline Independent variables & Method & Organization's profit \\
efficiency
\end{tabular}

\section{Source: Survey on March 2010}

Table4.13 reveals regression analysis result of organization's profit efficiency and its information about competitor's customer approaching and handling technique, customer's reason to shift in to competitor's offer, competitor's customer relationship management and competitor's product offering and customer attraction method. As it is shown by table 4.13 the coefficients of the correlation results are .068, .045, $.168^{*}$ and .037 which implies that organization's profit efficiency is positively related with its information about competitor's customer approaching and handling technique, customer's reason to shift in to competitor's offer, competitors customer relationship management and competitor's product offering and customer attraction method.

Table 4.14 Organization's overall status and its relationship with competition related variables $(\mathrm{N}=227)$ 


\begin{tabular}{|l|l|l|}
\hline Independent variables & Method & $\begin{array}{l}\text { Organization's } \\
\text { status }\end{array}$ \\
\hline Organization performance related question & Pearson & 1 \\
four & Correlation & \\
& Sig. (2-tailed) & \\
Competitor related question one & N & 227 \\
& Pearson & -.046 \\
& Correlation & \\
& Sig. (2-tailed) & .491 \\
& N & 227 \\
Competitor related question two & Pearson & -.047 \\
& Correlation & \\
& Sig. (2-tailed) & .485 \\
& N & 227 \\
Competitor related question three & Pearson & .029 \\
& Correlation & \\
& Sig. (2-tailed) & .664 \\
Competitor related question four & N & 227 \\
& Pearson & -.053 \\
& Correlation & \\
& Sig. (2-tailed) & .429 \\
& N & 227 \\
\hline
\end{tabular}

\section{Source: Survey on March 2010}

Table 4.14 reveals regression analysis result of organizations overall status and its information about competitor's customer approaching and handling technique, customer's reason to shift in to competitor's offer, competitors customer relationship management and competitor's product offering and customer attraction method. As it is shown by table 4.14 the coefficients of the correlation results are -.046, -.047, .029 and -.053 which indicates that organization's overall status is negatively related with and its information about competitor's customer approaching and handling technique, customer's reason to shift in to competitor's offer and competitor's product offering and customer attraction method while it is positively related with competitors customer relationship management method.

Table 4.15 Organization's sales efficiency and its relationship with product benefit related variables $(\mathrm{N}=227)$ 


\begin{tabular}{|c|c|c|c|}
\hline Independent variables & Method & $\begin{array}{l}\text { Organization's } \\
\text { efficiency }\end{array}$ & sales \\
\hline $\begin{array}{l}\text { Organization performance related question } \\
\text { one }\end{array}$ & $\begin{array}{l}\text { Pearson } \\
\text { Correlation } \\
\text { Sig. (2-tailed) } \\
\mathrm{N}\end{array}$ & 227 & \\
\hline Product benefit related question one & $\begin{array}{l}\text { Pearson } \\
\text { Correlation } \\
\text { Sig. (2-tailed) } \\
\text { N }\end{array}$ & $\begin{array}{l}.024 \\
.720 \\
227\end{array}$ & \\
\hline Product benefit related question two & $\begin{array}{l}\text { Pearson } \\
\text { Correlation } \\
\text { Sig. (2-tailed) } \\
\text { N }\end{array}$ & $\begin{array}{l}.067 \\
.315 \\
227\end{array}$ & \\
\hline Product benefit related question three & $\begin{array}{l}\text { Pearson } \\
\text { Correlation } \\
\text { Sig. (2-tailed) } \\
\mathrm{N}\end{array}$ & $\begin{array}{l}.125 \\
.059 \\
227\end{array}$ & \\
\hline Product benefit related question four & $\begin{array}{l}\text { Pearson } \\
\text { Correlation } \\
\text { Sig. (2-tailed) } \\
\text { N }\end{array}$ & $\begin{array}{l}.103 \\
.122 \\
227\end{array}$ & \\
\hline Product benefit related question five & $\begin{array}{l}\text { Pearson } \\
\text { Correlation } \\
\text { Sig. (2-tailed) } \\
\mathrm{N}\end{array}$ & $\begin{array}{l}-.045 \\
.499 \\
227\end{array}$ & \\
\hline
\end{tabular}

\section{Source: Survey on March 2010}

Table 4.15 shows regression analysis result of organization's sales efficiency and its value on customer preference during product offering process, market testing before launching the product, distribution strategy, quality of distribution system and product value for users. As it is shown by table 4.15 the coefficients of the correlation results are $.024, .067, .125, .103$ and -.045 which implies that organization's sales efficiency is positively related with its value on customer preference during product offering process, market testing before launching the product, distribution strategy and quality of distribution system while it is negatively related with product value for users.

Table 4.16 Organization's market share advantage and its relationship with product benefit related variables $(\mathrm{N}=227)$ 


\begin{tabular}{|c|c|c|}
\hline Independent variables & Method & $\begin{array}{l}\text { Organization's market share } \\
\text { advange }\end{array}$ \\
\hline $\begin{array}{lll}\text { Organization } & \text { performance } & \text { related } \\
\text { question two } & & \\
& & \end{array}$ & $\begin{array}{l}\text { Pearson } \\
\text { Correlation } \\
\text { Sig. (2-tailed) } \\
\mathrm{N}\end{array}$ & 227 \\
\hline Product benefit related question one & $\begin{array}{l}\text { Pearson } \\
\text { Correlation } \\
\text { Sig. (2-tailed) } \\
\mathrm{N}\end{array}$ & $\begin{array}{l}.069 \\
\\
.302 \\
227\end{array}$ \\
\hline Product benefit related question two & $\begin{array}{l}\text { Pearson } \\
\text { Correlation } \\
\text { Sig. (2-tailed) } \\
\mathrm{N}\end{array}$ & $\begin{array}{l}.062 \\
\\
.352 \\
227\end{array}$ \\
\hline Product benefit related question three & $\begin{array}{l}\text { Pearson } \\
\text { Correlation } \\
\text { Sig. (2-tailed) } \\
\text { N }\end{array}$ & $\begin{array}{l}.131^{*} \\
.049 \\
227\end{array}$ \\
\hline Product benefit related question four & $\begin{array}{l}\text { Pearson } \\
\text { Correlation } \\
\text { Sig. (2-tailed) } \\
\mathrm{N}\end{array}$ & $\begin{array}{l}.073 \\
\\
.270 \\
227\end{array}$ \\
\hline Product benefit related question five & $\begin{array}{l}\text { Pearson } \\
\text { Correlation } \\
\text { Sig. (2-tailed) } \\
\mathrm{N}\end{array}$ & $\begin{array}{l}.038 \\
\\
.570 \\
227\end{array}$ \\
\hline
\end{tabular}

Source: Survey on March 2010

Table 4.16 reveals regression analysis result of organization's market share advantage and its value on customer preference during product offering process, market testing before launching the product, distribution strategy, quality of distribution system and product value for users. As it is shown by table 4.16 the coefficients of the correlation results are .069, .062, $.131^{*}, .073$ and .038 which implies that organization's market share advantage is positively related with its value on customer preference during product offering process, market testing before launching the product, distribution strategy, quality of distribution system and product value for users.

Table 4.17 Organizations profit efficiency and its relationship with product benefit related variables $(\mathrm{N}=227)$ 


\begin{tabular}{|c|c|c|}
\hline Independent variable & Method & $\begin{array}{l}\text { Organization performance related } \\
\text { question three }\end{array}$ \\
\hline $\begin{array}{l}\text { Organization performance related } \\
\text { question three }\end{array}$ & $\begin{array}{l}\text { Pearson } \\
\text { Correlation } \\
\text { Sig. (2-tailed) } \\
\mathrm{N}\end{array}$ & 227 \\
\hline Product benefit related question one & $\begin{array}{l}\text { Pearson } \\
\text { Correlation } \\
\text { Sig. (2-tailed) } \\
\mathrm{N}\end{array}$ & $\begin{array}{l}.144^{*} \\
.030 \\
227\end{array}$ \\
\hline Product benefit related question two & $\begin{array}{l}\text { Pearson } \\
\text { Correlation } \\
\text { Sig. (2-tailed) } \\
\text { N }\end{array}$ & $\begin{array}{l}.105 \\
.116 \\
227\end{array}$ \\
\hline $\begin{array}{l}\text { Product benefit related question } \\
\text { three }\end{array}$ & $\begin{array}{l}\text { Pearson } \\
\text { Correlation } \\
\text { Sig. (2-tailed) } \\
\text { N }\end{array}$ & $\begin{array}{l}.027 \\
\\
.685 \\
227\end{array}$ \\
\hline Product benefit related question four & $\begin{array}{l}\text { Pearson } \\
\text { Correlation } \\
\text { Sig. (2-tailed) } \\
\text { N }\end{array}$ & $\begin{array}{l}.022 \\
.739 \\
227\end{array}$ \\
\hline Product benefit related question five & $\begin{array}{l}\text { Pearson } \\
\text { Correlation } \\
\text { Sig. (2-tailed) } \\
\mathrm{N}\end{array}$ & $\begin{array}{l}.082 \\
.217 \\
227\end{array}$ \\
\hline
\end{tabular}

Source: Survey on March 2010

Table 17 reveals regression analysis result of organization's profit efficiency and its value on customer preference during product offering process, market testing before launching the product, distribution strategy, quality of distribution system and product value for users. As it is shown by table 4.17 the coefficients of the correlation results are $.144^{*}, .105, .027, .022$ and .082 which indicates that organizations profit efficiency is positively related with its value on customer preference during product offering process, market testing before launching the product, distribution strategy, quality of distribution system and product value for users.

Table 4.18 Organization's overall status and its relationship with product benefit related variables $(\mathrm{N}=227)$ 


\begin{tabular}{|l|l|l|}
\hline Independent Variables & Method & $\begin{array}{l}\text { Organization } \\
\text { status }\end{array}$ \\
\hline Organization performance related question & Pearson & 1 \\
four & Correlation & \\
& Sig. (2-tailed) & \\
Product benefit related question one & N & 227 \\
& Pearson & -.031 \\
& Correlation & \\
& Sig. (2-tailed) & .644 \\
Product benefit related question two & N & 227 \\
& Pearson & -.069 \\
& Correlation & \\
Product benefit related question three & Sig. (2-tailed) & .302 \\
& N & 227 \\
& Pearson & -.007 \\
Product benefit related question four & Correlation & \\
& Sig. (2-tailed) & .915 \\
& N & 227 \\
& Pearson & -.065 \\
Product benefit related question five & Correlation & \\
& Sig. (2-tailed) & .327 \\
& N & 227 \\
& Pearson & Correlation \\
& Sig. (2-tailed) & .108 \\
\hline
\end{tabular}

\section{Source: Survey on March 2010}

Table 4.18 portrays regression analysis result of organization's overall status and its value on customer preference during product offering process, market testing before launching the product, distribution strategy, quality of distribution system and product value for users. As it is shown by table 4.18 the coefficients of the correlation results are -.031, -.069, -.007, -.065 and -.108 which implies that organization's overall status is negatively related with its value on customer preference during product offering process, market testing before launching the product, distribution strategy, quality of distribution system and product value for users.

Table 4.19 Organization's sales performance and its relationship with productivity related variables $(\mathrm{N}=\mathbf{2 2 7})$ 


\begin{tabular}{|l|l|l|}
\hline Independent variables & Method & $\begin{array}{l}\text { Organization's } \\
\text { efficiency }\end{array}$ \\
\hline Organization performance related question & Pearson & 1 \\
& Correlation & \\
& Sig. (2-tailed) & \\
one & N & 227 \\
& Pearson & -.008 \\
& Correlation & \\
& Sig. (2-tailed) & .899 \\
Productivity related question two & N & 227 \\
& Pearson & .098 \\
& Correlation & \\
& Sig. (2-tailed) & .142 \\
& N & 227 \\
& Pearson & .078 \\
& Correlation & \\
Productivity related question three & Sig. (2-tailed) & .244 \\
& N question one & 227 \\
& Pearson & .123 \\
& Correlation & \\
Productivity related question four & Sig. (2-tailed) & .063 \\
& N & 227 \\
& Pearson & $.137^{*}$ \\
& Correlation & \\
& Sig. (2-tailed) & .039 \\
\hline
\end{tabular}

Source: Survey on March 2010

Table 4.19 shows regression analysis result of organization's sales efficiency and customer's attitude on product quality, product effectiveness, product performance beyond consumer expectation, level of customer satisfaction relative to expectation and product overall performance. As it is shown by table 4.19 the coefficients of the correlation results are -.008, $.098, .098, .078, .123$ and $.137^{*}$ which implies that organization's sales efficiency is negatively related with customer's attitude on product quality while it is positively related with product effectiveness, product performance beyond consumer expectation, level of customer satisfaction relative to expectation and product overall performance.

Table 4.20 Organization's market share advantage and its relationship with productivity related variables $(\mathrm{N}=227)$ 


\begin{tabular}{|c|c|c|}
\hline Independent variable & Method & $\begin{array}{l}\begin{array}{l}\text { Organization's market } \\
\text { advantage }\end{array} \\
\end{array}$ \\
\hline $\begin{array}{lll}\text { Organization } & \text { performance } & \text { related } \\
\text { question two } & & \\
& & \end{array}$ & $\begin{array}{l}\text { Pearson } \\
\text { Correlation } \\
\text { Sig. (2-tailed) } \\
\mathrm{N}\end{array}$ & $\begin{array}{l}1 \\
227\end{array}$ \\
\hline Productivity related question one & $\begin{array}{l}\text { Pearson } \\
\text { Correlation }\end{array}$ & .068 \\
\hline & $\begin{array}{l}\text { Sig. (2-tailed) } \\
\mathrm{N}\end{array}$ & \\
\hline Productivity related question two & $\begin{array}{l}\text { Pearson } \\
\text { Correlation } \\
\text { Sig. (2-tailed) } \\
\text { N }\end{array}$ & $\begin{array}{l}.120 \\
.071 \\
227\end{array}$ \\
\hline Productivity related question three & $\begin{array}{l}\text { Pearson } \\
\text { Correlation } \\
\text { Sig. (2-tailed) } \\
\text { N }\end{array}$ & $\begin{array}{l}.112 \\
.093 \\
227\end{array}$ \\
\hline Productivity related question four & $\begin{array}{l}\text { Pearson } \\
\text { Correlation } \\
\text { Sig. (2-tailed) } \\
\text { N }\end{array}$ & $\begin{array}{l}.159^{*} \\
.016 \\
227\end{array}$ \\
\hline Productivity related question five & $\begin{array}{l}\text { Pearson } \\
\text { Correlation } \\
\text { Sig. (2-tailed) } \\
\text { N }\end{array}$ & $\begin{array}{l}.151^{*} \\
.023 \\
227\end{array}$ \\
\hline
\end{tabular}

Source: Survey on March 2010

Table 4.20 reveals regression analysis result of company's market share advantage and customer's attitude on product quality, product effectiveness, product performance beyond consumer expectation, level of customer satisfaction relative to expectation and product overall performance. As it is shown by table 4.20 the coefficients of the correlation results are .068, $.120, .112, .159^{*}$ and $.151^{*}$ which implies that company's market share advantage is positively related with customer's attitude on product quality, product effectiveness, product performance beyond consumer expectation, level of customer satisfaction relative to expectation and product overall performance.

Table 4.21 Organization's sales efficiency and its relationship with productivity related variables $(\mathrm{N}=227)$ 


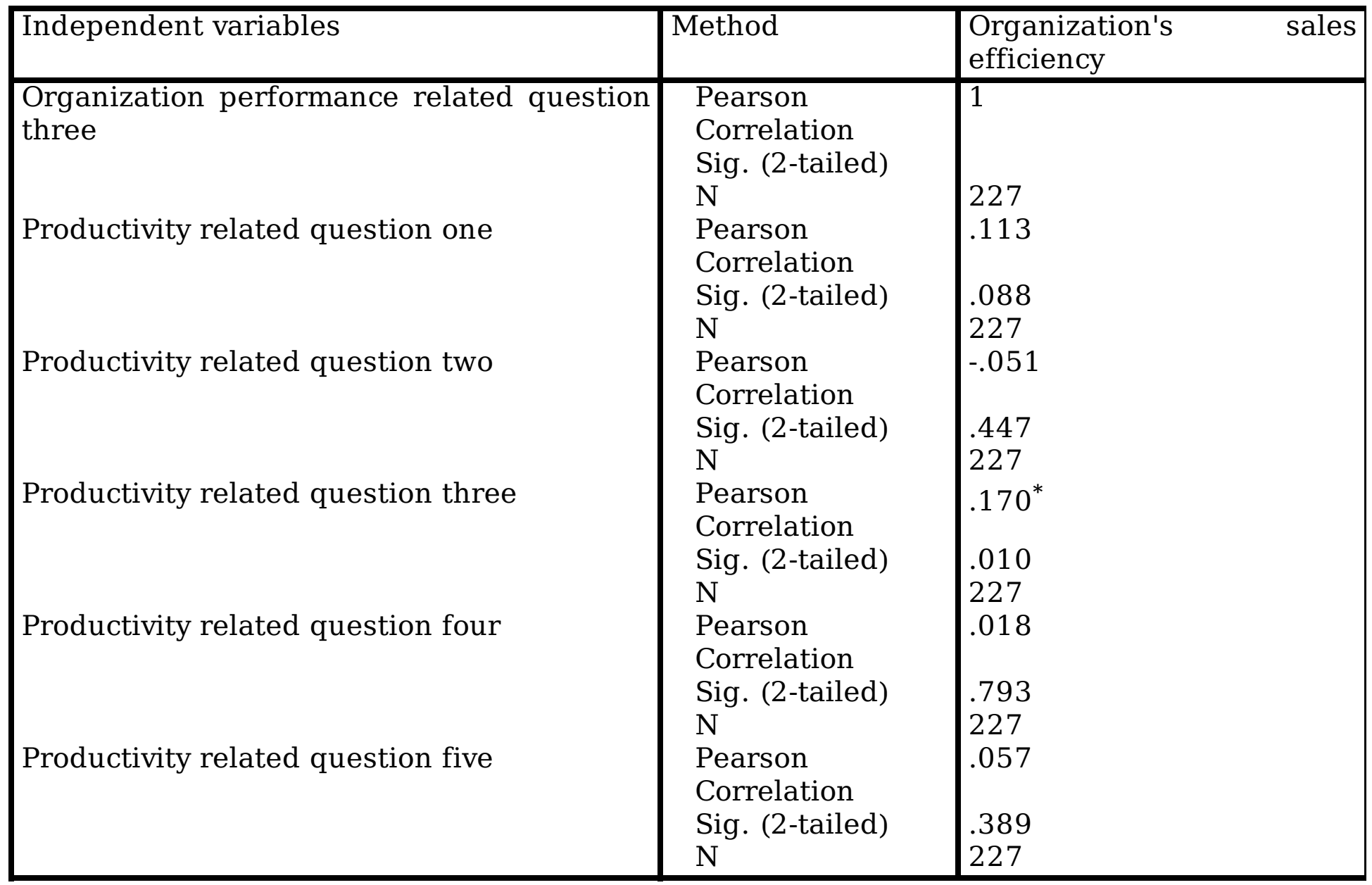

\section{Source: Survey on March 2010}

Table 4.21 shows regression analysis result of company's profit efficiency and customer's attitude towards product quality, product effectiveness, product performance beyond consumer expectation, level of customer satisfaction relative to expectation and product overall performance. As it is shown by table 4.21 the coefficients of the correlation results are .113, $-.051, .170^{*}, .018$ and .057 which indicates that organization's profit efficiency is positively related with customer's attitude towards product quality, product performance beyond consumer expectation, level of customer satisfaction relative to expectation and product overall performance while it is negatively related with product effectiveness.

Table 4.22 Organization's overall status and its relationship with productivity related variables $(\mathrm{N}=227)$ 


\begin{tabular}{|l|l|l|}
\hline Independent variables & Method & $\begin{array}{l}\text { Organization's } \\
\text { status }\end{array}$ \\
\hline Organization performance related question & Pearson & 1 \\
four & Correlation & \\
& Sig. (2-tailed) & 227 \\
Productivity related question one & N & -.070 \\
& Pearson & Correlation \\
& Sig. (2-tailed) & .296 \\
& N & 227 \\
Productivity related question two & Pearson & -.050 \\
& Correlation & \\
& Sig. (2-tailed) & .457 \\
Productivity related question three & N & 227 \\
& Pearson & -.082 \\
& Correlation & \\
& Sig. (2-tailed) & .217 \\
Productivity related question four & N & 227 \\
& Pearson & .070 \\
& Correlation & \\
Productivity related question five & Sig. (2-tailed) & .291 \\
& N & 227 \\
& Pearson & .007 \\
& Correlation & \\
& Sig. (2-tailed) & .911 \\
\hline
\end{tabular}

Source: Survey on March 2010

Table 4.22 shows regression analysis result of organization's overall status and customer's attitude towards product quality, product effectiveness, product performance beyond consumer expectation, level of customer satisfaction relative to expectation and product overall performance. As it is shown by table 4.22 the coefficients of the correlation results are -.070, $-.050,-.082, .070$ and .007 which implies that company's overall status is negatively related with customer's attitude on product quality, product effectiveness, product performance beyond consumer expectation while it is positively related with level of customer satisfaction relative to expectation and product overall performance.

Table 4.23 Organization's sales efficiency and its relationship with production process related variables $(\mathrm{N}=227)$ 


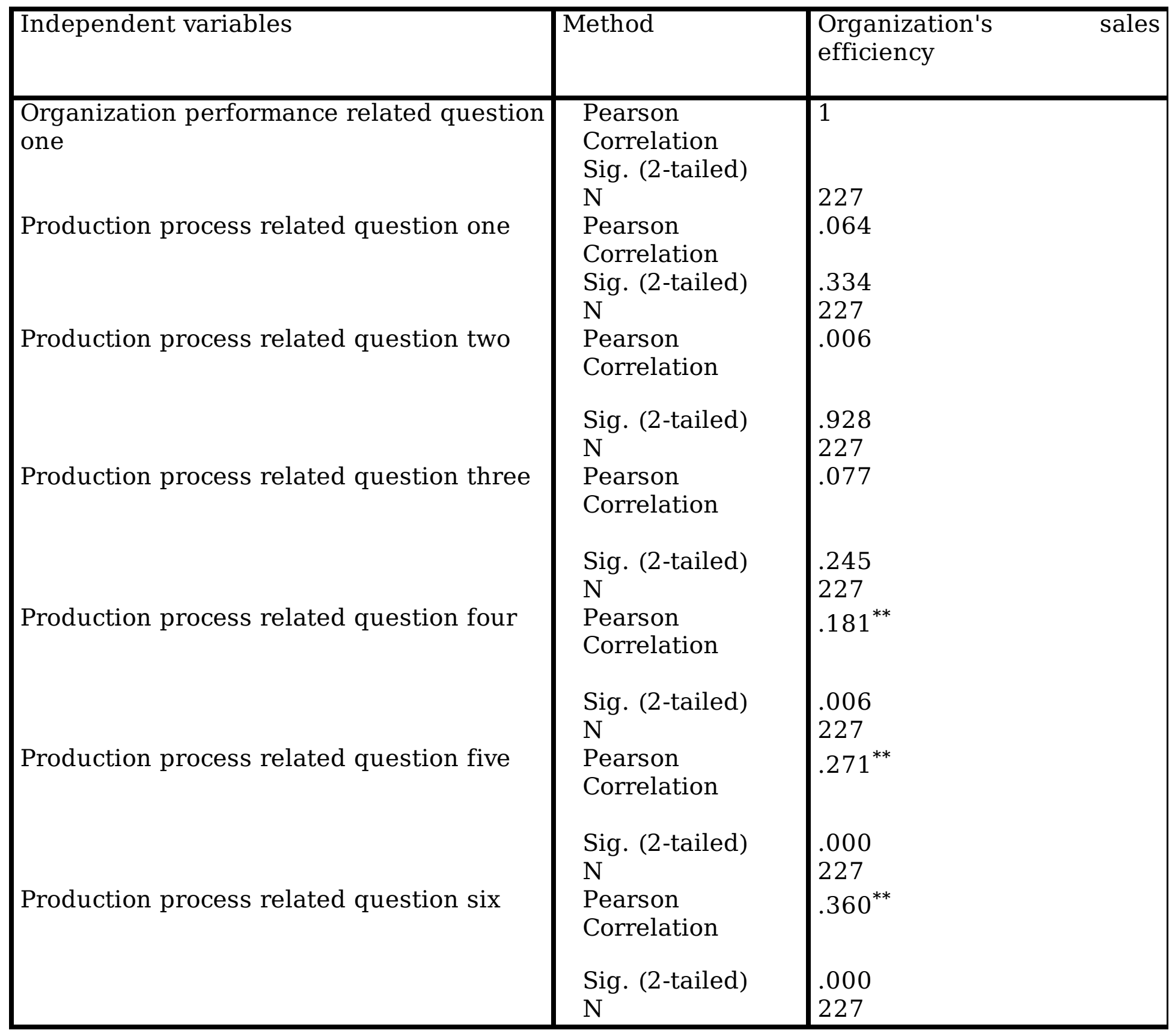

Source: Survey on March 2010

Table 4.23 reveals regression analysis result of organizations sales efficiency and its production plan, time and financial efficiency, operational strategy, market analysis before production and levels of customer involvement on product idea generation stage. As it is shown by table 4.23 the coefficients of the correlation results are $.064, .006, .077, .181^{* *}, .271^{* *}$ and $.360^{* *}$ which implies that company's sales efficiency is positively related with its production plan, time and financial efficiency, operational strategy, market analysis before production and levels of customer involvement on product idea generation stage.

Table 4.24 Organization's market share advantage and its relationship with production process related variables $(\mathrm{N}=227)$ 


\begin{tabular}{|c|c|c|}
\hline Independent Variables & Method & $\begin{array}{l}\text { Organization's market share } \\
\text { advantage }\end{array}$ \\
\hline $\begin{array}{lll}\text { Organization } & \text { performance } & \text { related } \\
\text { question two } & & \\
\end{array}$ & $\begin{array}{l}\text { Pearson } \\
\text { Correlation } \\
\text { Sig. (2-tailed) } \\
\text { N }\end{array}$ & 227 \\
\hline $\begin{array}{l}\text { Production process related question } \\
\text { one }\end{array}$ & $\begin{array}{l}\text { Pearson } \\
\text { Correlation } \\
\text { Sig. (2-tailed) } \\
\text { N }\end{array}$ & $\begin{array}{l}-.011 \\
.865 \\
227\end{array}$ \\
\hline $\begin{array}{l}\text { Production process related question } \\
\text { two }\end{array}$ & $\begin{array}{l}\text { Pearson } \\
\text { Correlation } \\
\text { Sig. (2-tailed) } \\
\text { N }\end{array}$ & $\begin{array}{l}-.025 \\
.704 \\
227\end{array}$ \\
\hline $\begin{array}{l}\text { Production process related question } \\
\text { three }\end{array}$ & $\begin{array}{l}\text { Pearson } \\
\text { Correlation } \\
\text { Sig. (2-tailed) } \\
\text { N }\end{array}$ & $\begin{array}{l}-.051 \\
.441 \\
227\end{array}$ \\
\hline $\begin{array}{l}\text { Production process related question } \\
\text { four }\end{array}$ & $\begin{array}{l}\text { Pearson } \\
\text { Correlation } \\
\text { Sig. (2-tailed) } \\
\text { N }\end{array}$ & $\begin{array}{l}.266^{* *} \\
.000 \\
227\end{array}$ \\
\hline $\begin{array}{l}\text { Production process related question } \\
\text { five }\end{array}$ & $\begin{array}{l}\text { Pearson } \\
\text { Correlation } \\
\text { Sig. (2-tailed) } \\
\text { N }\end{array}$ & $\begin{array}{l}.314^{* *} \\
.000 \\
227\end{array}$ \\
\hline Production process related question six & $\begin{array}{l}\text { Pearson } \\
\text { Correlation } \\
\text { Sig. (2-tailed) } \\
\mathrm{N}\end{array}$ & $\begin{array}{l}.473^{* *} \\
.000 \\
227 \\
\end{array}$ \\
\hline
\end{tabular}

Source: Survey on March 2010

Table 4.24 shows regression analysis result of company's market share advantage and its production plan, time and financial efficiency, operational strategy, market analysis before production and levels of customer involvement on product idea generation stage. As it is shown by table 4.24 the coefficients of the correlation results are $-.011,-.025,-.051, .266^{* *}, .314^{* *}$ and.473** which implies that organization's market share advantage is negatively related with its production plan, time and financial efficiency while it is positively related with its operational plan/strategy, market analysis before production and levels of customer involvement on product idea generation stage.

Table 4.25 Organization's profit efficiency and its relationship with production process related variables $(\mathrm{N}=227)$ 


\begin{tabular}{|l|l|l|}
\hline Independent variables & Method & $\begin{array}{l}\text { Organization's } \\
\text { efficiency }\end{array}$ \\
\hline Organization performance related question & Pearson & 1 \\
& Correlation \\
& Sig. (2-tailed) & \\
& N & 227 \\
three & Pearson & .028 \\
& Correlation & \\
& Sig. (2-tailed) & .680 \\
& N & 227 \\
Production process related question two & Pearson & -.035 \\
& Correlation & \\
& Sig. (2-tailed) & .596 \\
& N & 227 \\
Production process related question three & Pearson & .033 \\
& Correlation & \\
& Sig. (2-tailed) & .621 \\
& N & 227 \\
Production process related question four & Pearson & .056 \\
& Correlation & \\
& Sig. (2-tailed) & .403 \\
& N & 227 \\
Production process related question five & Pearson & $.187^{* *}$ \\
& Correlation & \\
& Sig. (2-tailed) & .005 \\
& N & 227 \\
Production process related question six & Pearson & $.275^{* *}$ \\
& Correlation & \\
& Sig. (2-tailed) & .000 \\
& N & 227 \\
\hline
\end{tabular}

Source: Survey on March 2010

Table 4.25 reveals regression analysis result of company's profit efficiency and its production plan, time and financial efficiency, operational strategy, market analysis before production and levels of customer involvement on product idea generation stage. As it is shown by table 4.25 the coefficients of the correlation results are $.028,-.035, .033, .056, .187^{* *}$ and $.275^{* *}$ which indicates that organization's profit efficiency is positively related with and its production plan, operational strategy, market analysis before production while it is negatively related with time and financial efficiency.

Table 4.26 Organization's overall status and its relationship with production process related variables $(\mathrm{N}=\mathbf{2 2 7})$ 


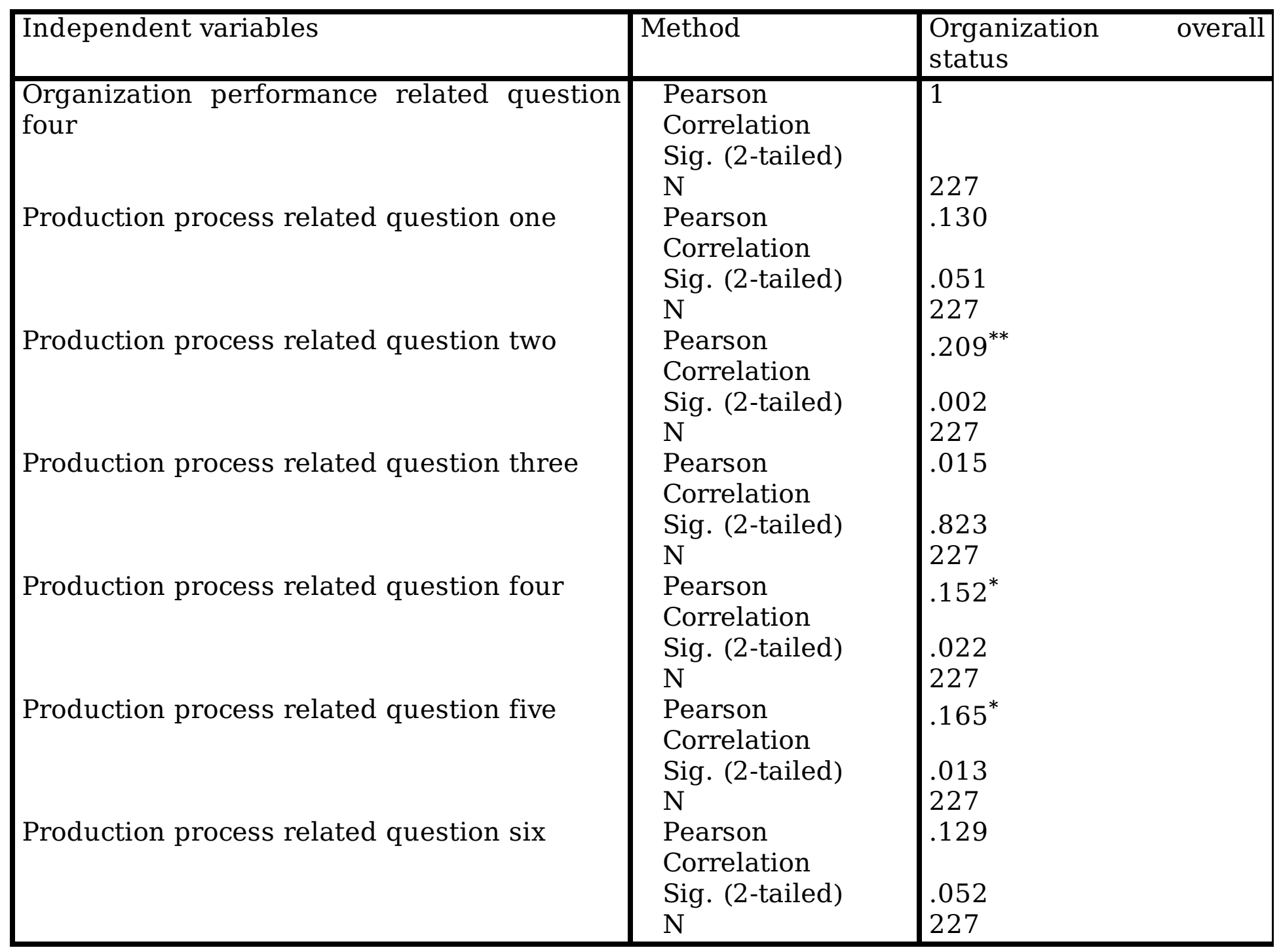

Source: Survey on March 2010

Table 4.26 reveals regression analysis result of organization's overall performance and its production plan, time and financial efficiency, operational strategy, market analysis before production and levels of customer involvement on product idea generation stage. As it is shown by table 4.26 the coefficients of the correlation results are $.130, .209^{* *}, .015, .152^{*}, .165^{*}$ and .129 which implies that company's overall status is positively related with its production plan, time and financial efficiency, operational strategy, market analysis before production and levels of customer involvement on product idea generation stage.

Table 4.27 Firm's market directed operation and its relationship with performance related variables overall status $(\mathrm{N}=227)$ 


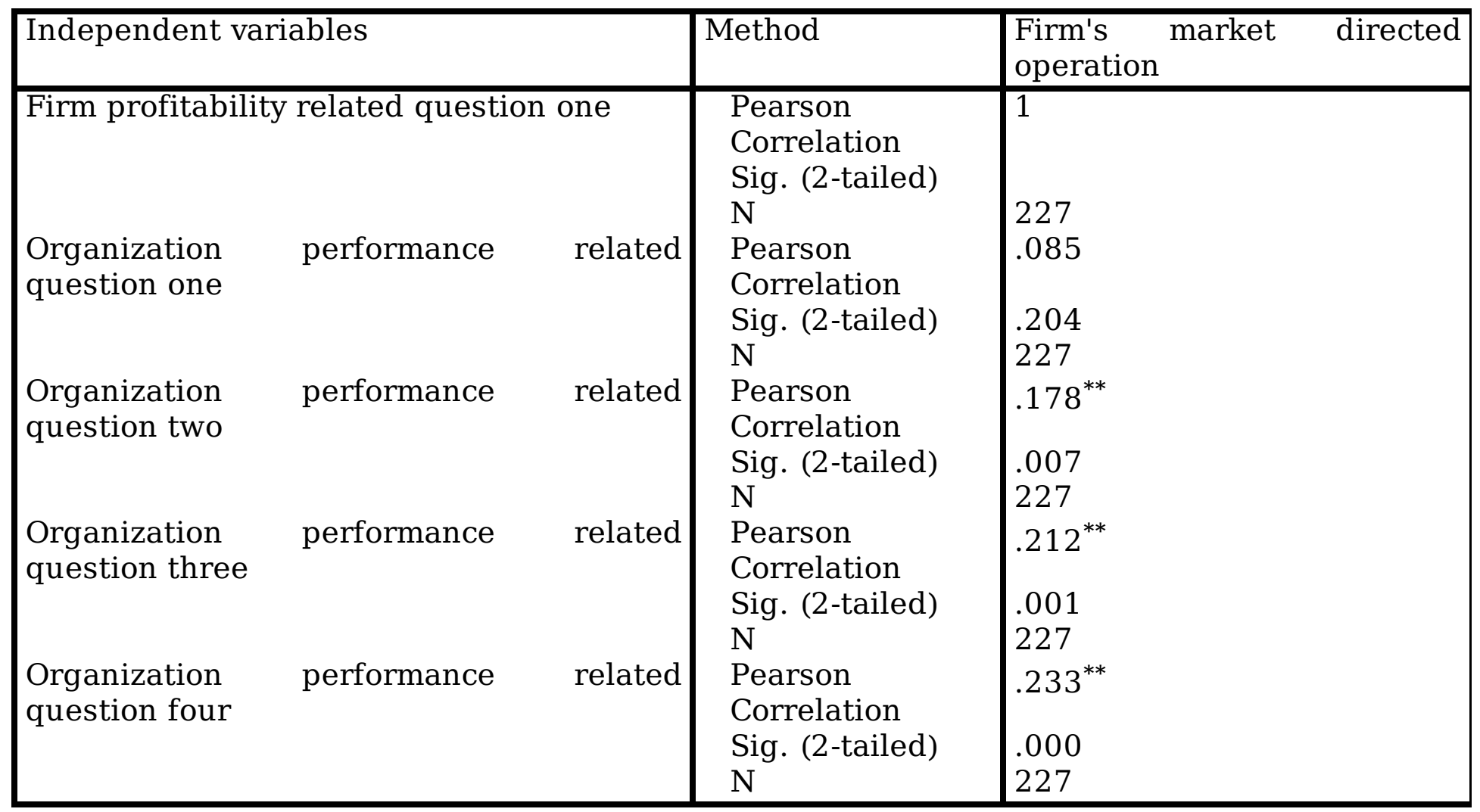

Source: Survey on March 2010

Table 4.27 shows regression analysis result of firm's market directed operation and its sales efficiency, market share advantage, profit efficiency and overall status. As it is shown by table 4.27 the coefficients of the correlation results are $.085, .178^{* *}, .212^{* *}$ and $.233^{* *}$ which implies that company's market oriented operation is directly related with its sales efficiency, market share advantage, profit efficiency and overall status.

Table 4.28 Firm's customer oriented operation and its relation with performance related variables $(\mathrm{N}=227)$ 


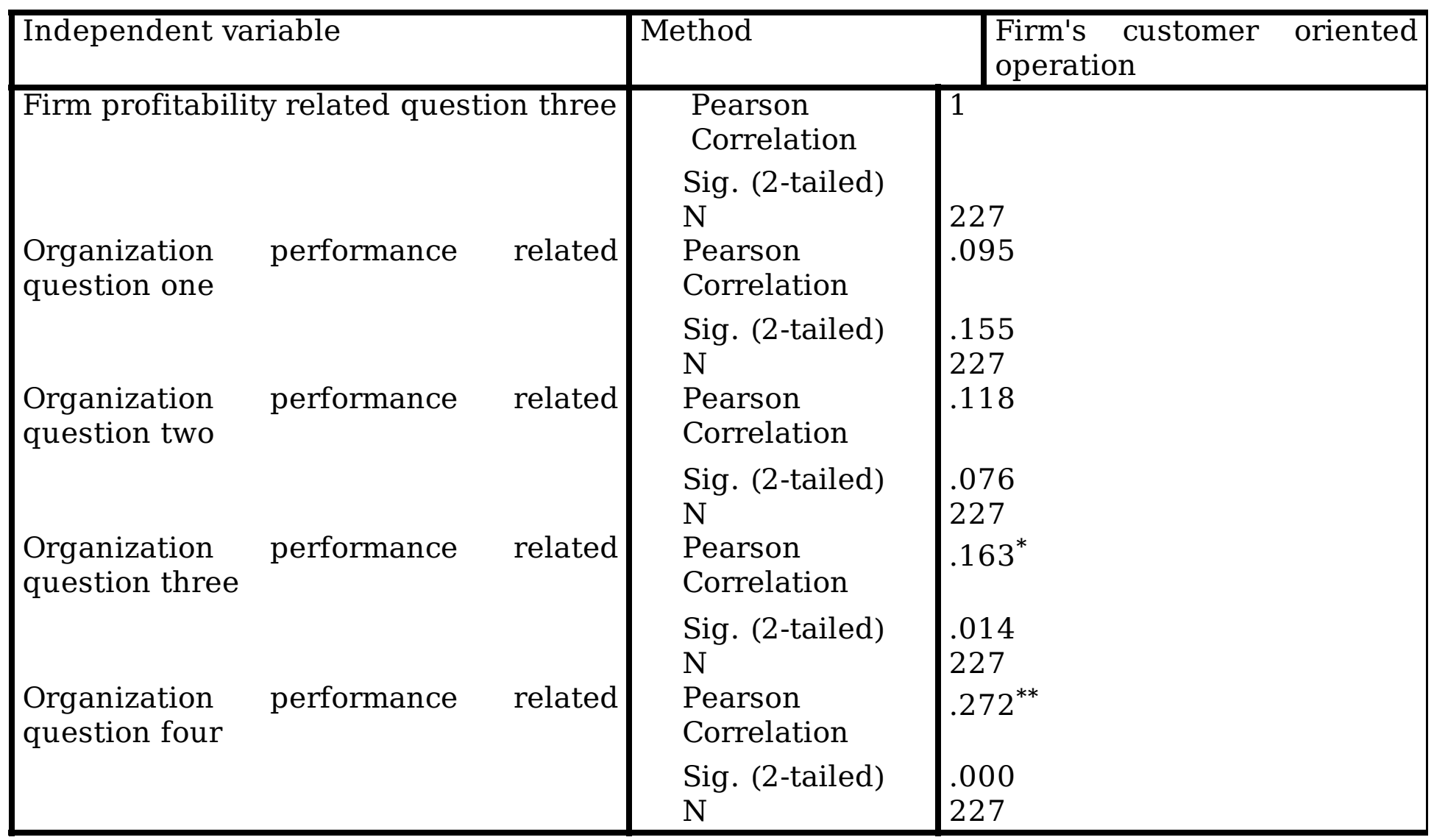

Source: Survey on March 2010

Table 4.28 reveals regression analysis result of firm's customer oriented operation and its sales efficiency, market share advantage, profit efficiency and overall status. As it is shown by table 4.28 the coefficients of the correlation results are $.095, .118, .163^{*}$ and $.272^{* *}$ which indicates that company's customer oriented operation is positively related with its sales efficiency, market share advantage, profit efficiency and overall status.

Table 4.29 Firm's competitor oriented operation and its relationship with performance related variables $(\mathrm{N}=227)$ 


\begin{tabular}{|c|c|c|}
\hline Independent variables & Method & $\begin{array}{l}\text { Firm's competitor oriented } \\
\text { operation }\end{array}$ \\
\hline Firm profitability related question four & $\begin{array}{l}\text { Pearson } \\
\text { Correlation } \\
\text { Sig. (2-tailed) } \\
\mathrm{N}\end{array}$ & $\begin{array}{l}1 \\
227\end{array}$ \\
\hline $\begin{array}{l}\text { Organization performance related } \\
\text { question one }\end{array}$ & $\begin{array}{l}\text { Pearson } \\
\text { Correlation } \\
\text { Sig. (2-tailed) } \\
\mathrm{N}\end{array}$ & $\begin{array}{l}.101 \\
.128 \\
227\end{array}$ \\
\hline $\begin{array}{l}\text { Organization performance related } \\
\text { question two }\end{array}$ & $\begin{array}{l}\text { Pearson } \\
\text { Correlation } \\
\text { Sig. (2-tailed) } \\
\mathrm{N}\end{array}$ & $\begin{array}{l}.132^{*} \\
.048 \\
227\end{array}$ \\
\hline $\begin{array}{l}\text { Organization performance related } \\
\text { question three }\end{array}$ & $\begin{array}{l}\text { Pearson } \\
\text { Correlation } \\
\text { Sig. (2-tailed) } \\
\text { N }\end{array}$ & $\begin{array}{l}.089 \\
.180 \\
227\end{array}$ \\
\hline $\begin{array}{l}\text { Organization performance } \\
\text { question four }\end{array}$ & $\begin{array}{l}\text { Pearson } \\
\text { Correlation } \\
\text { Sig. (2-tailed) } \\
\mathrm{N}\end{array}$ & $\begin{array}{l}.237^{* *} \\
.000 \\
227\end{array}$ \\
\hline
\end{tabular}

Source: Survey on March 2010

Table 4.29 shows regression analysis result of firm's competitor oriented operation and its sales efficiency, market share advantage, profit efficiency and overall status. As it is shown by table 4.29 the coefficients of the correlation results are $.101, .132^{*}, .089$ and $.237^{* *}$ which indicates that firm's competitor oriented operation is positively related with and its sales efficiency, market share advantage, profit efficiency and overall status.

Table 4.30 Firm's production process operation and its relationship with performance related variables $(\mathrm{N}=227)$ 


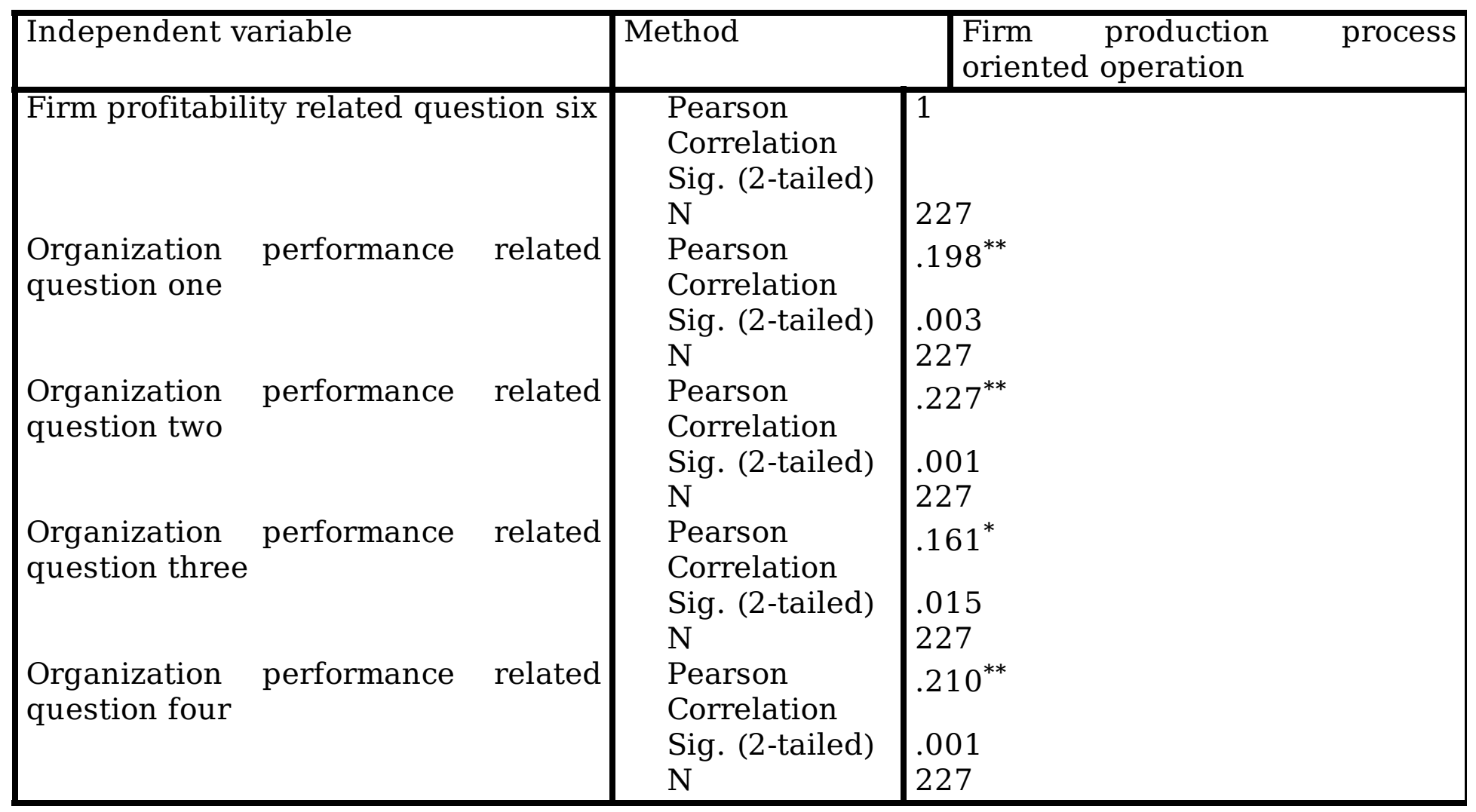

\section{Source: Survey on March 2010}

Table 4.30 reveals regression analysis result of firm production process oriented operation and its sales efficiency, market share advantage, profit efficiency and overall status. As it is shown by table 4.30 the coefficients of the correlation results are $.198^{* *}, .227^{* *}, .161^{*}$ and $.210^{* *}$ which implies that firm production process oriented operation is positively related with its sales efficiency, market share advantage, profit efficiency and overall status.

Table 4.31 Firm's product oriented operation and its relationship with performance related variables $(\mathrm{N}=227)$ 


\begin{tabular}{|c|c|c|}
\hline Independent variables & Method & $\begin{array}{ll}\text { Firm product } & \text { oriented } \\
\text { operation }\end{array}$ \\
\hline Firm profitability related question seven & $\begin{array}{l}\text { Pearson } \\
\text { Correlation } \\
\text { Sig. (2-tailed) } \\
\text { N }\end{array}$ & $\begin{array}{l}1 \\
227\end{array}$ \\
\hline $\begin{array}{l}\text { Organization performance related question } \\
\text { one }\end{array}$ & $\begin{array}{l}\text { Pearson } \\
\text { Correlation } \\
\text { Sig. (2-tailed) } \\
\text { N }\end{array}$ & $\begin{array}{l}.126 \\
.058 \\
227\end{array}$ \\
\hline $\begin{array}{l}\text { Organization performance related question } \\
\text { two }\end{array}$ & $\begin{array}{l}\text { Pearson } \\
\text { Correlation } \\
\text { Sig. (2-tailed) } \\
\text { N }\end{array}$ & $\begin{array}{l}.216^{* *} \\
.001 \\
227\end{array}$ \\
\hline $\begin{array}{l}\text { Organization performance related question } \\
\text { three }\end{array}$ & $\begin{array}{l}\text { Pearson } \\
\text { Correlation } \\
\text { Sig. (2-tailed) } \\
\text { N } \\
\text { Pearson } \\
\text { Correlation } \\
\text { Sig. (2-tailed) } \\
\text { N }\end{array}$ & $\begin{array}{l}.191^{* *} \\
.004 \\
227 \\
.186^{* *} \\
.005 \\
227\end{array}$ \\
\hline
\end{tabular}

Source: Survey on March 2010

Table 4.31 reveals regression analysis result of company's product oriented operation and its sales efficiency, market share advantage, profit efficiency and overall status. As it is shown by table 4.30 the coefficients of the correlation results are $.126, .216^{* *}, .191^{* *}$ and $.186^{* *}$ which implies that company's product oriented operation is directly related with its sales efficiency, market share advantage, profit efficiency and overall status.

\section{Conclusions And Recommendations}

\subsection{Conclusions}

This examination was directed to explore, portray and report the relationship between advertise direction, as far as market itself, client, rivalry, creation process, efficiency item execution, authoritative execution and productivity. Thus in the wake of get-together the asked information from the objective respondents utilizing a study poll, straight relapse examination was made utilizing measurable bundle for sociology to evaluate the connection between the autonomous factors (contenders creation limit, item quality as far as creation information and nature of organization's general data taking care of and scattering process, its data taking care of capacity about shopper's purchasing procedure, data with respect to buyer's grievances its contribution on client relationship the executives and its capacity to risk clients neighborly, organization's data about rival's client drawing closer and taking care of system, client's motivation to move in to contender's offer, rivals client relationship the executives and contender's item offering and client fascination technique, organization's an incentive on client inclination during item offering process, showcase testing before propelling the item, dissemination methodology, nature of dispersion framework and item esteem for clients, client's demeanor on item quality, item adequacy, item execution past 
purchaser desire, level of consumer loyalty comparative with desire and item in general execution, company's creation plan, time and monetary productivity, operational methodology, advertise investigation before creation and levels of client association on item thought age stage) and ward variables(company's business proficiency, piece of the pie advantage serious position, benefit in general status and gainfulness). Likewise specialists finish up the accompanying dependent on the investigation results.Organization's sales efficiency is positively related with its product quality, consumer's buying process, consumer's complaints its involvement on customer relationship management, consumer involvement of product idea generation stage, customer's reason to shift in to competitor's offer, and competitor's product offering and customer attraction method.

- Company's piece of the overall industry is decidedly related with its item quality, efficiency, client relationship the board strategy, client mentality, observation, client fascination and dealing with, consumer loyalty item execution, authoritative execution and productivity.

- Organizational execution is legitimately related with item execution, advertising plan execution, serious position and operational system, showcase direction and dispatch methodology.

- Firm's degree of gainfulness is emphatically related with item quality, nature of dispersion framework, consumer loyalty, client observation, item position, client relationship the board, item execution and authoritative execution so benefit and money related execution can be improved.

\section{Abbreviations}

BGI- Borders Group Inc.

NPD - New product development

IMO-International Maritime Organization

ROA- Return on asset

\section{References}

1. Hunt, S.D. \& Morgan, R. (1995). "The Comparative Advantage Theory of Competition", Journal of Marketing, 59 (2): 1-15.

2. Kohli, A.K. and Jaworski, B.J. (1990) Market orientation: the construct, research propositions and managerial implications. Journal of Marketing 54, April, 1-18.

3. Homburg and Pflesser (2000) A systematic literature review of internal capabilities for enhancing eco-innovation performance of manufacturing firms VL - 209

4. Igor Ansoff (1987), 'Concept of Strategy', in Corporate Strategy, London: Penguin Books, pp. 100-116

5. Kotler, P. (2000) Marketing Management the Millennium Edition. Person Prentice Hall, Upper Saddle River. 
6. Schumpeter, J.A., 1934 (2008), the Theory of Economic Development: An Inquiry into Profits, Capital, Credit, Interest and the Business Cycle, New Brunswick (U.S.A) and London (U.K.): Transaction Publishers.

7. Geroski, P, M., Machin, S.and Reenen, J. (1993). The Profitability of Innovating Firms. Rand Journal of Economics24 (2):198-211.

8. Clark, K. B. and Fujimoto, T. (1991). Product Development Performance: Strategy, Organization, and Management in the World Auto Industry. Boston: Harvard Business School Press.

9. Goedhuys, M. and Veugelers, R. (2008). Innovation strategies, process and product innovations and growth: Firm-level evidence from Brazil. Department of Managerial Economics, Strategy and Innovation (MSI)

10. Anurag, S. and Nelson, L. (2004). Linking Product Development Outcomes to Market Valuation of the Firm: The Case of the U.S. Pharmaceutical Industry. Journal of product Innovation Management

11. Dirk Heremans, 2007. "Corporate governance issues for banks. A financial stability perspective," Working Papers of Department of Economics, Leuven ces0707, KU Leuven, Faculty of Economics and Business (FEB), Department of Economics, Leuven.

12. Rutagi . R (1997), Performance of parastatal Organizations in Uganda.

13. R.N. (2002). Board of Directors Composition, Team Processes and Organizational performance of selected financial institutions in Uganda. Unpublished Research Dissertation submitted in partial fulfillment for the award of a degree at Makerere University.

14. Epstein (2003)Relations Between Continuous Performance Test Performance Measures and ADHD Behaviors VL - 31 Journal of abnormal child psychology

15. Zahra, S., \& Hayton, J. (2008). The Effect of International Venturing on Firm Performance: The Moderating Influence of Absorptive Capacity. Journal of business venturing, 2008(23), 1995-220.

16. Brush, C. G., \& Vanderwerf, P. A. (1992). A comparison of methods and sources for obtaining estimates of new venture performance. Journal of Business Venturing, 7(2), 157-170.

17. Murphy, G. B., Trailer, J. W., \& Hill, R. C. 1996. Measuring performance in entrepreneurship research. Journal of Business Research, 36: 15-23.

18. Pérez-Luñoa, A., Wiklundb, J., \& Cabrera, R. A. (2011). The dual nature of innovative activity: How entrepreneurial orientation influences innovation generation and adoption. Journal of Business Venturing, 26(5) 555-571

19. Kotler, P. (2003) Marketing Management. 11th Edition, Prentice-Hall, Upper Saddle River.

20. Pandian, J.R, Thomas, H. Furrer, O. \& Bogner, W.C. (2006). Performance differences across strategic groups: an examination offinancial market-based performance measures. Strategic Change, 15(6), 373-383.

21. Calantone and di Benedetto (1988) An Integrative Model of the New Product Development Process An Empirical Validation Pages 201-215 
22. Lukas, B.A. and Ferrell, O.C. (2000) the effect of market orientation on product innovation. Journal of the Academy of Marketing Science28 (2), 239-47.

23. Bennett, R.C., \& Cooper.R.C. (1981). "The misuse of Marketing: An American Tragedy", Business Horizons, 24 (6): 51-61.

24. Christensen, C.M. and Bower, J.L. (1996) Customer Power, Strategic Investment and the Failure of Leading Firms. Strategic Management Journal, 17, 197-218.

25. Slater, S.F. and Narver, J.C. (1994a) Does competitive environment moderate the market orientationperformance relationship? Journal of Marketing 58, January, 46-55.

26. Slater, S.F. and Narver, J.C. (1994b) Market orientation, customer value, and superior performance. Business Horizons37, March-April, 22-8.

27. Baker, W. E., and Sinkula, J. M. (1999a), "The Synergistic Effect of Market Orientation and Learning Orientation on Organizational Performance," Journal of the Academy of Marketing Science, Vol. 27 (Fall), pp. 411-27

28. Pelham, Alfred M, and David T, Wilson (1996), "A LongitudinalStudy of the Impact of Market Structure, Firm Structure, Strat-egy, and Market Orientation Culture on Dimensions of Small-Firm Perfonnance," Journal of the Academy of Marketing Sci-ence, 24 (1),27-A3.

29. Szymanski, D.M. and Henard, D.H. (2001) Customer Satisfaction: A Meta-Analysis of the Empirical Evidence. Journal of the Academy of Marketing Science, 29, 16-35.

30. Atuahene-Gima, K. (1996) Market Orientation and Innovation. Journal of Business Research, 35, 93103.

31. Hultink, Erik (1998) Launch decisions and new product success: an empirical comparison of consumer and industrial products VL - 17 Journal of Product Innovation Management

32. Deshpandé, J. U. Farley (1998), "Factors Affecting Organizational Performance: A Five-Country Comparison," Amos Tuck School, Dartmouth College, Working Paper.

33. Baker, W. E., and Sinkula, J. M. (1999a), "The Synergistic Effect of Market Orientation and Learning Orientation on Organizational Performance," Journal of the Academy of Marketing Science, Vol. 27 (Fall), pp. 411-27.

34. Atuahene-Gima, K. (1995) An Exploratory Analysis of the Impact of Market Orientation on New Product Performance. Journal of Product Innovation Management, 12, 275-293. http://dx.doi.org/10.1016/0737-6782(95)00027-Q

35. Rogers, E.M. (1983) Diffusion of Innovations. Free Press, New York.

36. Hubert Gatignon and Thomas S Robertson, (1985), A Propositional Inventory for New Diffusion Research, Journal of Consumer Research, 11, (4), 849-67

37. Henard, David Szymanski, David( 2001) Customer Satisfaction: A Meta-Analysis of the Empirical Evidence VL - 29 16-35, Journal of the Academy of Marketing Science

38. Montoya-Weiss, Roger Calantone(1994)Determinants of new product performance: A review and meta-analysis Determinants of new product performance: $A$ review and meta-analysis Journal of 
Product Innovation Management v-11, 397-417

39. Maidique, Modesto A. and Zirger, Billie Jo, A Study of Success and Failure in Product Innovation: The Case of the U.S. Electronics Industry (1984). IEEE Transactions on Engineering Management, Vol. EM-31, Issue 4, p. 192-203 1984. Available at SSRN: https://ssrn.com/abstract=150635

40. Song, M., \& Parry, M. E. (1996). What separates Japanese new product winners from losers? Journal of Product Innovation Management, 13(3), 1-14

41. Cooper, R. G. (1979). The dimensions of industrial new product success and failure. Journal of Marketing, 43(2), 93-103.

42. Cooper, R. G., \& Kleinschmidt, E. J. (1987). New products: What separates winners from losers? Journal of Product Innovation Management, 4(3), 169-184

43. Song, M., \& Parry, M. E. (1997a). The determinants of Japanese new product successes. Journal of Marketing Research, 34(1), 64-76.

44. Song, M., \& Parry, M. E. (1997b). A cross-national comparative study of new product development processes: Japan and the United States. Journal of Marketing, 61(2), 1-18.

45. Harrington J.W, Green et al. (1995), Strategy formulation, organizational learning, and location New Technology and Regional Development, 2003

46. Griffin, A. (1992). Evaluating QFD's use in U.S. firms as a process for developing products. Journal of Product Innovation Manage-ment, 9(3), 171-182

47. Kohli, A. K., \& Jaworski, B. J. (1990). Market orientation: the construct, research propositions, and managerial implications. Journal of Marketing, 54(2), 1-18.

48. Griffin, A. H., \& Robben, H. S. J. (1997). Industrial new product launch strategies and product development performance. Journal of Product Innovation Management, 14, 243-257.

49. Terwiesch, Christian, and Christoph H. Loch. "Measuring the Effectiveness of Overlapping Development Activities." Management Science, vol. 45, no. 4, 1998, pp. 455-465. JSTOR, jstor.org/stable/2634817.

50. Cooper, D.R. and Schindler, P.S. (2003) Business Research Methods. 8th Edition, McGraw-Hill Irwin, Boston.

\section{Figures}




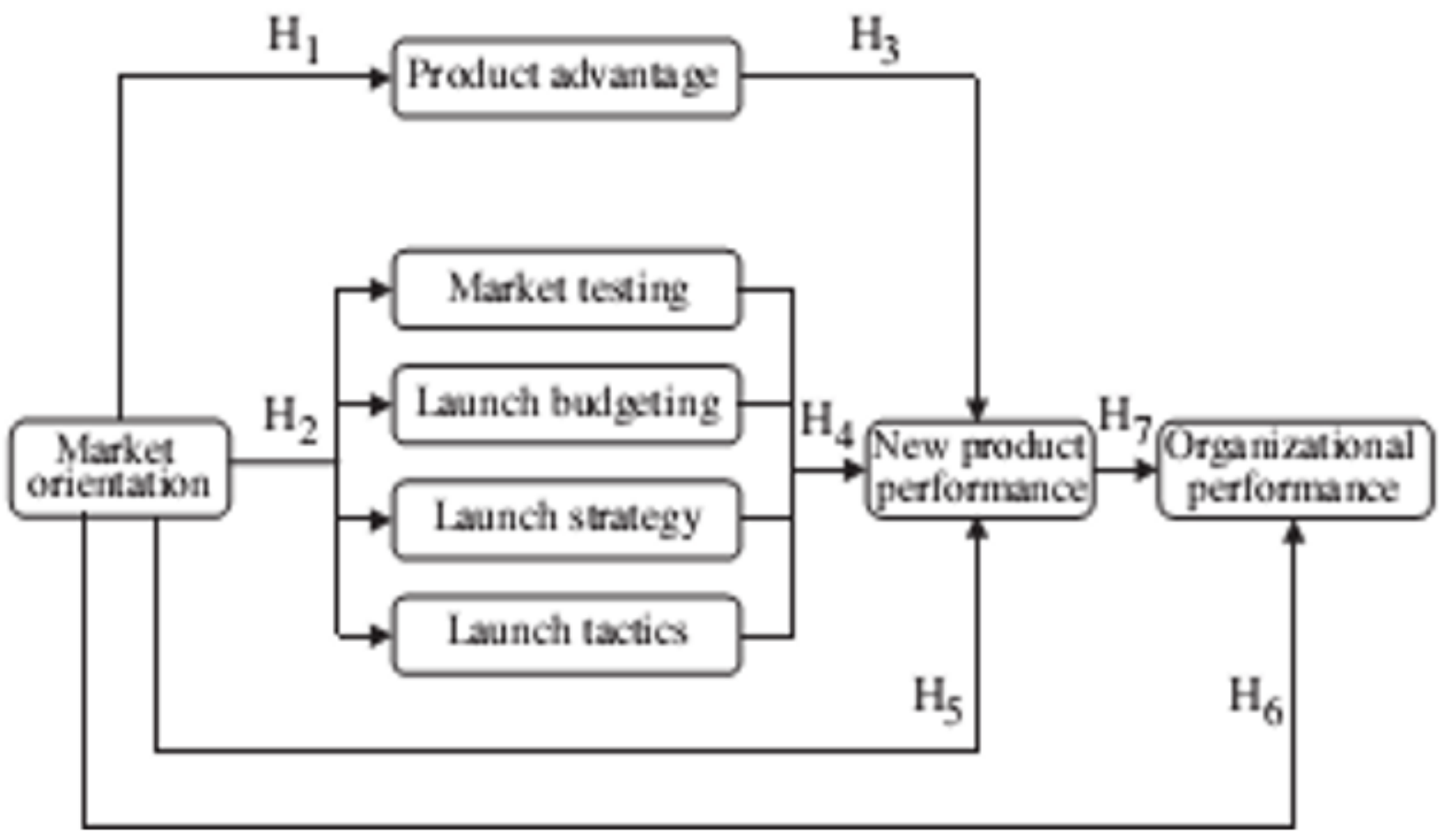

Figure 1

conceptual framework Adapted from different literatures 